\title{
Review
}

\section{HIV-1 infection and AIDS: consequences for the central nervous system}

\author{
M Kaul $^{1}$, J Zheng ${ }^{2}$, S Okamoto ${ }^{1}$, HE Gendelman ${ }^{2}$ and \\ SA Lipton*,1 \\ 1 Center for Neuroscience and Aging Research, The Burnham Institute, 10901 \\ North Torrey Pines Road, La Jolla, CA 92037, USA \\ 2 Departments of Pharmacology and Pathology and Microbiology, Center for \\ Neurovirology and Neurodegenerative Disorders, 985880 Nebraska Medical \\ Center, University of Nebraska Medical Center, Omaha, NE 68198-5880, USA \\ * Corresponding author: SA Lipton, Center for Neuroscience and Aging \\ Research, The Burnham Institute, 10901 North Torrey Pines Road, La Jolla, \\ CA 92037, USA. Tel: 858713 6261; Fax: 858713 6262; \\ E-mail: slipton@ burnham.org
}

Received 16.12.04; revised 14.2.05; accepted 21.2.05; published online 15.4.05 Edited by M Piacentini

\begin{abstract}
Infection with the human immunodeficiency virus-1 (HIV-1) can induce severe and debilitating neurological problems that zymes and glutamate receptor-mediated excitotoxicity, all of and disrupt neuronal and glial function. This review will discuss recently uncovered pathologic neuroimmune and of future therapeutic intervention.

Cell Death and Differentiation (2005) 12, 878-892.

doi:10.1038/sj.cdd. 4401623

Published online 15 April 2005
\end{abstract} include behavioral abnormalities, motor dysfunction and frank dementia. After infiltrating peripheral immune competent cells, in particular macrophages, HIV-1 provokes a neuropathological response involving all cell types in the brain. HIV-1 also incites activation of chemokine receptors, inflammatory mediators, extracellular matrix-degrading enwhich can trigger numerous downstream signaling pathways degenerative mechanisms contributing to neuronal damage induced by HIV-1 and potential approaches for development

Keywords: HIV-1; NeuroAIDS; neurodegeneration; apoptosis; immune activation; macrophages/microglia; neurotoxicity; pharmacology; inflammation; central nervous system

Abbreviations: HIV-1, human immunodeficiency virus-1; AIDS, acquired immunodeficiency syndrome; CNS, central nervous system; CSF, cerebrospinal fluid; HAD, HIV-associated dementia; MCMD, minor cognitive motor disorder; HAART, highly active antiretroviral therapy; BBB, blood-brain barrier; SDF-1, stromal cell-derived factor; TNF, tumor necrosis factor; TRAIL, TNFrelated apoptosis-inducing ligand; $\mathrm{MCP}$, monocyte chemoattractant protein; MIP, macrophage inflammatory protein; RANTES, regulated upon activation-normal $\mathrm{T}$-cell expressed and secreted

\section{Introduction}

Human immunodeficiency virus-1 (HIV-1) can not only destroy the immune system and lead to acquired immunodeficiency syndrome (AIDS), but the virus can also induce neurological disease that culminates in frank dementia. The worldwide development of HIV-related disease is alarming, with more than 36 million existing infections, and about 20 million deaths. ${ }^{1}$ AIDS opportunistic infections may affect the central nervous system (CNS), but HIV infection itself can also induce a number of neurological syndromes. ${ }^{2}$ Interestingly, anemia in HIV-1 infection seems to be an early predictor for a high risk of neuropsychological impairment. ${ }^{3}$ Neuropathological conditions directly triggered by HIV-1 include peripheral neuropathies, vacuolar myelopathy and a syndrome of cognitive and motor dysfunction that has been designated HIV-associated dementia (HAD). ${ }^{2,4-6}$ A mild form of HAD is termed minor cognitive/motor disorder (MCMD). ${ }^{2,4,6,7}$

The mechanism of HAD and MCMD remains poorly understood, but the discovery in the brain of cellular binding sites for HIV-1, the chemokine receptors, and recent progress in neural stem cell biology are providing new and hitherto unexpected insights. It is widely believed that HIV entry into the CNS occurs via infected monocytes. ${ }^{8-10}$ Interestingly, in the brain, HIV-1 productively infects only macrophages and microglia, but injury and apoptotic death occur in neurons. ${ }^{11,12}$ Activation of monocytic cells (macrophages and microglia) through infection, viral proteins or inflammatory mediators and their subsequent release of toxins apparently lead to neuronal and astrocytic dysfunction and thus seem to drive the pathogenesis of HAD. ${ }^{4,13-15}$ However, viral proteins might also directly contribute to neuronal injury. Some of the neurotoxic factors excessively stimulate neurons, thus leading to excitotoxicity with subsequent breakdown in neurons of vital cellular functions in a manner shared with other neurodegenerative diseases. ${ }^{4,15}$ Advances in understanding the molecular mechanisms of the disease-defining events provide hope for improved therapeutic intervention. ${ }^{16,17}$

\section{Epidemiology of HAD before and in the Era of HAART}

In the early 1990s, the prevalence of HAD was estimated to be as high as $20-30 \%$ of those individuals with advanced HIV disease and low CD4 cell counts $\left(<200 \mu \mathrm{l}^{-1}\right)$. $^{3}$ The introduction of highly active antiretroviral therapy (HAART) has increased the life expectancy of people infected with HIV-1 and resulted in an at least temporary decrease in the incidence of HAD to as low as $10.5 \% .{ }^{18-20}$ In fact, a case studied by our group demonstrated near-complete reversal of clinical signs and symptoms of HAD that has been sustained for more than 7 years. ${ }^{21}$ However, while improvements in 
control of peripheral viral replication and the treatment of opportunistic infections continue to extend survival times, HAART failed to provide complete protection from HAD or to reverse the disease in most cases. ${ }^{22,23}$ This might at least in part be due to poor penetration into the CNS of HIV protease inhibitors and several of the nucleoside analogs. ${ }^{24}$ Therefore, an early CNS infection might evolve independently over time into a protected brain reservoir. In fact, distinct viral drug resistance patterns in the plasma and cerebrospinal fluid (CSF) compartments have recently been reported. ${ }^{25}$ Consequently, as people live longer with HIV-1 and AIDS, the prevalence of dementia might be rising and in recent years the incidence of HAD as an AIDS-defining illness has actually increased. $^{22,26,27}$ Furthermore, the proportion of new cases of HAD displaying a CD4 cell count greater than $200 \mu \mathrm{l}^{-1}$ is growing, ${ }^{18}$ and MCMD may be more prevalent than frank dementia in the HAART era. ${ }^{7}$ However, HAD might currently be the most common cause of dementia worldwide among people aged 40 or less, and it remains a significant independent risk factor for death due to AIDS. ${ }^{7}$ Thus, a better understanding of the pathogenesis of $H A D$, including viral and host factors, is needed in order to identify additional therapeutic targets for the prevention and treatment of this neurodegenerative disease.

\section{From HIV Entry into the Brain to Development of MCMD/HAD}

Soon after infection in the periphery HIV penetrates into the CNS where the virus primarily resides in microglia and macrophages. ${ }^{8,9}$ Viral load in brain can be measured by quantitative PCR, and the highest concentrations of virus are detected in those subcortical structures most often affected in patients with HAD. ${ }^{28,29}$ However, infection of macrophages and microglia alone does not seem to initiate neurodegeneration, and it has therefore been proposed that additional factors associated with advanced HIV infection in the periphery, thus outside the CNS, provide important triggers for events leading to dementia. ${ }^{9}$ An elevated number of circulating monocytes that express CD16 and CD69 could constitute one such factor. These activated cells tend to adhere to and transmigrate through the normal endothelium of the brain microvasculature and might then initiate processes deleterious to neurons. ${ }^{9}$

The blood-brain barrier (BBB) also plays a crucial role in HIV infection of the CNS. ${ }^{30-32}$ Microglia and astrocytes produce chemokines - cell migration/chemotaxis-inducing cytokines - such as monocyte chemoattractant protein (MCP)-1, which appear to regulate migration of peripheral blood mononuclear cells through the BBB. ${ }^{32}$ In fact, a mutant MCP-1 allele that causes increased infiltration of mononuclear phagocytes into tissues has recently been implicated in an increased risk of HAD. ${ }^{33}$ Histological studies in specimens from HIV-1-infected humans and SIV-infected rhesus macaques found that lymphocytes and monocytes enter the brain. ${ }^{34,35}$ The pathophysiological relevance of CNS-invading lymphocytes in HAD is not clearly established. ${ }^{35,36}$ However, infiltrating lymphocytes and activated microglia in brains with HIV-1 encephalitis showed strong immunoreactivity for inter- leukin (IL)-16, a natural ligand of CD4. Since this cytokine inhibits HIV-1 propagation, lymphocytes might contribute to an innate antiviral immune response in the CNS in addition to microglia. ${ }^{37}$ Cell migration also engages adhesion molecules, and increased expression of vascular cell adhesion molecule1 (VCAM-1) has been implicated in mononuclear cell migration into the brain during HIV and SIV infection. ${ }^{30,31,38}$ As an alternative to entry via infected macrophages, it has been suggested that the inflammatory cytokine, tumor necrosis factor-alpha (TNF- $\alpha$ ), promotes a paracellular route for HIV-1 across the BBB. ${ }^{39}$ Interestingly, alterations in the BBB occur even in the absence of intact virus in transgenic mice expressing the HIV envelope protein gp120 in a form that circulates in plasma. ${ }^{40}$ This finding suggests that circulating virus or envelope proteins may provoke BBB dysfunction during the viremic phase of primary infection. On the part of the host, a vicious cycle of immune dysregulation and BBB dysfunction might be required to achieve sufficient entry of infected or activated immune cells into the brain to cause neuronal injury. ${ }^{4,41}$ On the side of the virus, variations of the envelope protein gp120 might also influence the timing and extent of events allowing viral entry into the CNS and leading to neuronal injury. ${ }^{42}$

\section{Potential Links between Neuropathology of HIV Infection and Pathogenesis of HAD}

The neuropathological hallmarks of HIV infection in the brain are termed HIV encephalitis and include widespread reactive astrocytosis, myelin pallor, microglial nodules, activated resident microglia, multinucleated giant cells, and infiltration predominantly by monocytoid cells, including blood-derived macrophages. ${ }^{43}$ Surprisingly, measures of cognitive function do not correlate well with numbers of HIV-infected cells, multinucleated giant cells or viral antigens in CNS tissue. ${ }^{44,45}$ In contrast, increased numbers of microglia, ${ }^{44}$ elevated TNF- $\alpha$ mRNA in microglia and astrocytes, ${ }^{46}$ evidence of excitotoxins, ${ }^{47-49}$ decreased synaptic and dendritic density, ${ }^{45,50}$ and selective neuronal loss ${ }^{51,52}$ constitute the pathologic features most closely associated with the clinical signs of HAD. Furthermore, signs of neuronal apoptosis have been linked to $\mathrm{HAD},{ }^{53-55}$ although this finding is not clearly associated with viral burden ${ }^{53}$ or a history of dementia. ${ }^{56}$ The localization of apoptotic neurons is correlated with evidence of structural atrophy and closely associated with signs of microglial activation, especially within subcortical deep gray structures, ${ }^{56}$ which may show a predilection for atrophy in HAD.

The neuropathology observed in post-mortem specimens from HAD patients in combination with extensive studies using both in vitro and animal models of HIV-induced neurodegeneration has led to a fairly complex model for the pathogenesis of HAD. The available information strongly suggests that the pathogenesis of HAD might be most effectively explained when viewed as similar to the multihit model of oncogenesis. Figure 1 shows a model of potential intercellular interactions and alterations of normal cell functions that can lead to neuronal injury and death in the setting of HIV infection. ${ }^{4}$ Macrophages and microglia can be infected by HIV-1, but they can also be activated by factors released from 


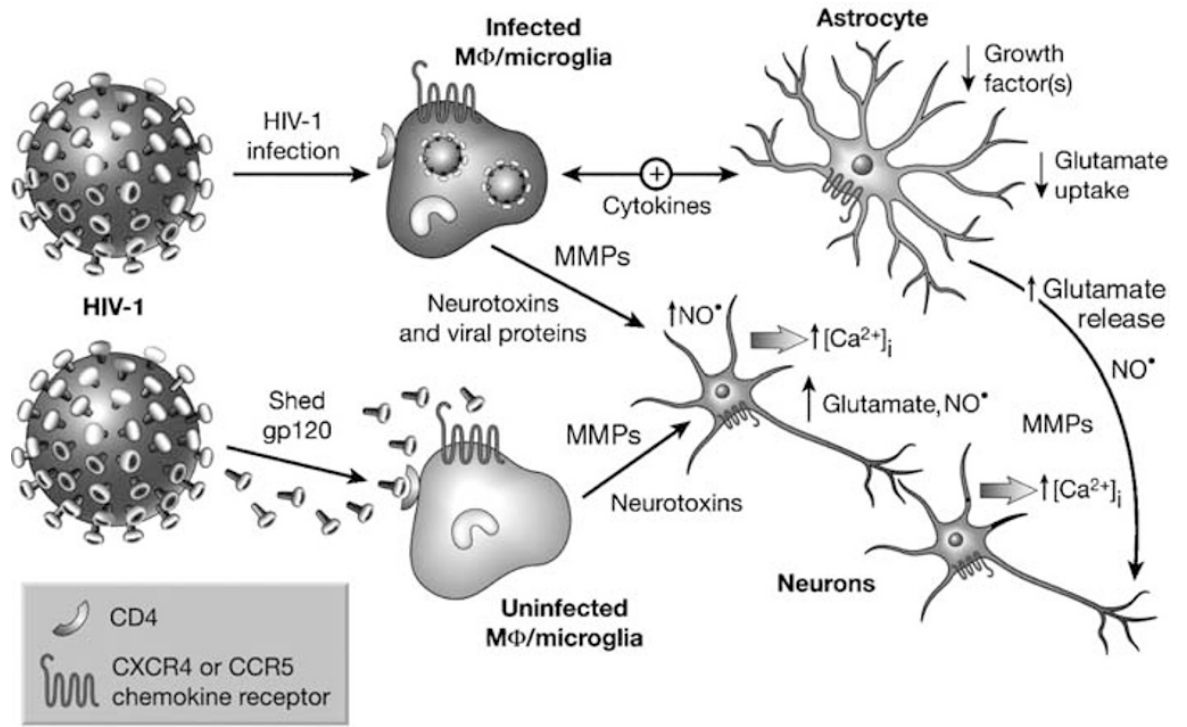

Figure 1 Current model of neuronal injury and death induced by HIV-1 infection. Immune-activated and HIV-infected brain macrophages (MФ)/microglia release potentially neurotoxic substances. These substances include quinolinic acid and other excitatory amino acids (EAAs) such as glutamate and L-cysteine, arachidonic acid, platelet-activating factor (PAF), NTox, free radicals, TNF- $\alpha$, and probably others. These factors from macrophages and also possibly from reactive astrocytes contribute to neuronal injury, dendritic and synaptic damage, and apoptosis as well as to astrocytosis. Entry of HIV-1 into monocytoid cells occurs via gp120 binding, and therefore it is not surprising that gp120 (or a fragment thereof) is capable of activating uninfected macrophages to release similar factors to those secreted in response to productive HIV infection. Macrophages express CCR5 and CXCR4 chemokine receptors on their surface in addition to CD4, and gp120 binds via these receptors. Some populations of neurons and astrocytes have been reported to also possess CXCR4 and CCR5 receptors on their surface, raising the possibility of direct interaction with gp120. Macrophages/microglia and astrocytes have mutual feedback loops (bidirectional arrow). Cytokines participate in this cellular network in several ways. For example, HIV infection or gp120 stimulation of macrophages enhances their production of TNF- $\alpha$ and IL-1 $\beta$ (arrow). The TNF- $\alpha$ and IL- $1 \beta$ produced by macrophages stimulate astrocytosis. Arachidonate released from macrophages impairs astrocyte clearing of the neurotransmitter glutamate and thus contributes to excitotoxicity. In conjunction with cytokines, the $\alpha$-chemokine stromal cell-derived factor (SDF)-1 stimulates reactive astrocytes to release glutamate in addition to the free radical nitric oxide [NO•], which in turn may react with superoxide $\left(\mathrm{O}_{2}^{-}\right)$to form the neurotoxic molecule peroxynitrite $\left(\mathrm{ONOO}^{-}\right)$. NO might also activate extracellular matrix metalloproteinases (MMPs), which can then proteolytically affect neurons, and also cleave membrane-anchored fractalkine. ${ }^{131,198}$ Neuronal injury is primarily mediated by overactivation of NMDARs with resultant excessive influx of $\mathrm{Ca}^{2+}$. This in turn leads to overactivation of a variety of potentially harmful signaling systems, the formation of free radicals and release of additional neurotransmitter glutamate. Glutamate subsequently overstimulates NMDARs on neighboring neurons, resulting in further injury. This final common pathway of neurotoxic action can be blocked by NMDAR antagonists. For certain neurons, depending on their exact repertoire of ionic channels, this form of damage can also be ameliorated to some degree by calcium channel antagonists or non-NMDAR antagonists. Additionally, agonists of $\beta$ chemokine receptors, which are present in the CNS on neurons, astrocytes and microglia, can confer partial protection against neuronal apoptosis induced by HIV/gp120 or NMDA. The figure is modified from Kaul et al. ${ }^{4}$

infected cells. These factors include cytokines and shed viral proteins such as gp120. Variations of the HIV-1 envelope protein gp120, in particular in its $\mathrm{V} 1, \mathrm{~V} 2$ and $\mathrm{V} 3$ loop sequences, have been implicated in modulating the activation of macrophages and microglia. ${ }^{42}$ Factors released by activated microglia affect all cell types in the CNS, resulting in upregulation of cytokines, chemokines and endothelial adhesion molecules. ${ }^{4,9,15}$ Some of these factors may directly or indirectly contribute to neuronal damage and apoptosis. Directly neurotoxic factors released from activated microglia include excitatory amino acids (EAAs) and related substances, such as quinolinate, cysteine and a not completely characterized amine compound named 'Ntox'. ${ }^{13,49,57-61}$ EAAs induce neuronal apoptosis through a process known as excitotoxicity. This detrimental process engenders excessive $\mathrm{Ca}^{2+}$ influx and free radical (nitric oxide (NO) and superoxide anion) formation by overstimulation of glutamate receptors. ${ }^{58,62}$ Certain HIV proteins, such as gp120 and Tat, have also been reported to be directly neurotoxic, although high concentrations of viral protein may be needed, or neurons may have to be cultured in isolation to see these direct effects. ${ }^{63,64}$ It is important to note that toxic viral proteins among factors released from microglia and glutamate set free by astrocytes may act in concert to promote neurodegeneration, even in the absence of extensive viral invasion of the CNS.

\section{Chemokine Receptors in HIV-1 Infection and HAD}

Chemokine receptors are seven transmembrane-spanning domain, G-protein-coupled receptors, and as such trigger intracellular signaling events. While chemokines and their receptors were originally shown to mediate leukocyte trafficking and to contribute intimately to the organization of inflammatory responses of the immune system, they are now known to contribute to far more physiological and pathological processes. ${ }^{41,65,66}$ The additional functions include the intricate control of organogenesis, including hematopoiesis, angiogenesis and development of heart and brain. ${ }^{67-70}$ Furthermore, chemokines and their receptors are 
essential for maintenance, maturation and migration of hematopoietic and neural stem cells. ${ }^{66,71}$ However, the most prominent pathological function of certain chemokine receptors seems to be the mediation of HIV-1 infection. ${ }^{70,72,73}$

Infection of macrophages and lymphocytes by HIV-1 can occur after binding of the viral envelope protein gp120 to one of several possible chemokine receptors in conjunction with CD4. Generally, T cells are infected via the $\alpha$-chemokine receptor CXCR4 and/or the $\beta$-chemokine receptor CCR5. In contrast, macrophages and microglia are primarily infected via the $\beta$-chemokine receptor CCR5 or CCR3, but the $\alpha$ chemokine receptor CXCR4 may also be involved. ${ }^{74-77}$ The HIV coreceptors CCR5 and CXCR4, among other chemokine receptors, are also present on neurons and astrocytes, ${ }^{78,79}$ although these cells are not thought to harbor productive infection. Several in vitro studies strongly suggest that CXCR4 is directly involved in HIV-associated neuronal damage while CCR5 may additionally serve a protective role. ${ }^{63,80,81}$

In cerebrocortical neurons and neuronal cell lines from humans and rodents, picomolar concentrations of HIV-1 gp120, as well as intact virus, can induce neuronal death via CXCR4 receptors. ${ }^{76,77,80-82}$ In mixed neuronal/glial cerebrocortical cultures that mimic the cellular composition of the intact brain, this apoptotic death appears to be mediated predominantly via the release of microglial toxins rather than by direct neuronal damage. ${ }^{77,81,82}$ However, nanomolar concentrations of SDF- $1 \alpha / \beta$ interacting with $\mathrm{CXCR} 4$ can induce apoptotic death of neurons in the absence of microglia, suggesting a possible direct interaction with neurons while interaction with astrocytes can also occur. ${ }^{81,83,84}$ In contrast to these findings, it has been reported that somewhat higher concentrations of SDF-1 $\alpha$ provide neuroprotection from X4preferring gp120-induced damage of isolated hippocampal neurons. 63

Using mixed neuronal/glial cerebrocortical cultures from rat and mouse, we have further investigated the role of chemokine receptors in the neurotoxicity of gp120. We found that gp120 from CXCR4 (X4)-preferring as well as CCR5 (R5)-preferring and dual tropic HIV-1 strains all were able to trigger neuronal death. While gp120 from one out of two X4-preferring HIV-1 strains no longer showed neurotoxicity in CXCR4-deficient cerebrocortical cultures, dual tropic gp120 ${ }_{\text {SF2 }}$ showed, surprisingly, even greater neurotoxicity in CCR5 knockout cultures compared to wild-type or CXCR4deficient cultures. ${ }^{85}$ These findings are consistent with a primarily neurotoxic effect of CXCR4 activation by gp120. In contrast, activation of CCR5 might at least in part be neuroprotective depending on the HIV-1 strain from which a given gp120 originated. Furthermore, we observed earlier that the CCR5 ligands macrophage inflammatory protein (MIP)-1 $\beta$ and regulated upon activation-normal T-cell expressed and secreted (RANTES) protect neurons against gp120-induced toxicity. ${ }^{81}$

Since in vitro inhibition of microglial activation is sufficient to prevent neuronal death after gp120 exposure, it seems likely that stimulation of CXCR4 in macrophages/microglia is a prerequisite for the neurotoxicity of gp120. ${ }^{76,81}$ In contrast, SDF-1 might directly activate CXCR4 in astrocytes and neurons to trigger neuronal death, for example, by reversing glutamate uptake in astrocytes. $.^{4,80,81,84} \mathrm{SDF}-1$ is produced by astrocytes, macrophages, neurons and Schwann cells. ${ }^{83,86-88}$ An increase in SDF-1 mRNA has been detected in HIV encephalitis ${ }^{79}$ and protein expression of SDF-1 also appears to be elevated in the brains of HIV patients. ${ }^{89}$ To what degree the increased expression of SDF-1 aggravates neuronal damage by HIV-1 remains to be shown. We had reported previously that intact SDF-1 can be toxic to mature neurons in a CXCR4-dependent manner, at least in culture. ${ }^{81,83,85}$ Additionally, it was recently reported that cleavage of SDF-1 by MMPs may contribute to neuronal injury and thus HAD via a non-CXCR4-mediated mechanism. ${ }^{90}$ Importantly, increased expression and activation of MMPs, including MMP-2 and MMP-9, were detected in HIV-infected macrophages and also in post-mortem brain specimens from AIDS patients compared with uninfected controls. ${ }^{91}$ As elegantly shown by Power and colleagues, MMP-2 released from HIV-infected macrophages is able to proteolytically remove four amino acids from the N-terminus of SDF-1. This truncated form of SDF-1 no longer binds CXCR4 and is an even more powerful neurotoxin than full-length SDF-1. ${ }^{90}$

\section{Effect of Chemokines and HIV/gp120 on Neural Stem and Progenitor Cells}

CXCR4 is expressed on neurons, microglia, astrocytes and endothelia in the brain. ${ }^{83,92,93}$ However, this chemokine receptor and its ligand SDF-1 are also major components in many physiological processes involving hematopoietic and neural stem cells. ${ }^{36,66,94}$ This indicates that HIV-1 could also directly interfere with biological functions of neural stem and progenitor cells.

Neural stem cells and later progenitor cells are widely thought to provide a reservoir to replace neurons or glia under conditions of brain injury or disease. ${ }^{95}$ Neurogenesis can be stimulated by ischemic and excitotoxic brain injuries, physical exercise, diet, learning or an enriched environment, ${ }^{41,96}$ and may decrease with aging. ${ }^{97}$ Functionally, it is suggested that this neurogenesis contributes to long-term synaptic plasticity and cognitive processes and is also involved in pathological processes such as depression. ${ }^{98,99}$ Three important steps are involved in neurogenesis and regulation of neural progenitor cells (NPCs): directed migration, proliferation and differentiation. ${ }^{100}$ Chemokines such as SDF-1 and its receptor CXCR4 appear to play an important role in the process. CXCR4 is highly expressed during development in the cerebellum, hippocampus and neocortex, and this expression persists into adulthood. ${ }^{67,69,101-103}$ SDF-1 transcripts are predominantly expressed by oligodendrocytes, astrocytes and neurons in the neocortex, hippocampus and cerebellum ${ }^{87,103}$ and by meningeal cells. ${ }^{102}$ In vitro, the production of SDF-1 by purified astrocyte cultures is associated with a macrophageastrocyte interaction. ${ }^{83}$ Whether or not SDF-1/CXCR4 interaction is involved in all of the above-mentioned three steps of neurogenesis is not known; however, it has been documented that SDF-1/CXCR4 signaling regulates migration of NPCs in the cerebellum, dentate gyrus and cortex. ${ }^{67,69,102,103}$ Furthermore, it has recently been reported that the recruitment of CXCR4-positive progenitor cells into regenerating tissue is mediated by a hypoxic gradient and expression of SDF-1 that 
is induced by the transcription factor hypoxia-inducible factor1 (HIF-1). ${ }^{104}$ Thus, several lines of evidence indicate a significant involvement of the SDF-1/CXCR4 interaction in tissue damage and repair.

In order to investigate this possibility, we utilized cultures of primary mouse and human neural progenitor cells obtained during the fetal period. These cells stain positively for the neural stem cell marker nestin and readily undergo cell division. After several rounds of proliferation, the progenitors exit the cell cycle and express neuronal markers such as $\beta$ IIItubulin (TuJ1). Our immunocytochemical studies showed that the progenitors are positive for CXCR4 and CCR5. Treatment with HIV-1/gp120 reduced the number of progenitors and differentiating neurons. Accounting for these observations, we found that gp120 inhibited proliferation of neural progenitor cells without producing apoptosis. The resulting decrease in neural stem cell proliferation engendered by gp120 also means that there are fewer progenitor cells present to differentiate in neurons, thus impairing neurogenesis ( $S$ Okamoto, S McKercher, M Kaul and SA Lipton, unpublished). Recently, these findings were complemented and extended by others using commercially generated human neural progenitor cells. ${ }^{105,106}$ In those experiments, chemokines promoted the quiescence and survival of human neural progenitor cells via stimulation of CXCR4 and CCR3 via a mechanism that involves downregulation of extracellularly regulated kinase-1 and -2 (ERK-1/2) and simultaneous upregulation of Reelin. ${ }^{105}$ Exposure to HIV-1 appeared to induce quiescence of neural progenitors, also through engagement of CXCR4 and CCR3. The coat protein HIV-1/ gp120 reportedly downregulated ERK-1/2 but had no effect on the neuronal glycoprotein Reelin. ${ }^{106}$ The effects of both the chemokines and HIV-1/gp120 were reversible and could be inhibited with recombinant apolipoprotein E3 (ApoE3), but not ApoE4. The finding that HIV-1/gp120 could indeed interfere with the normal function of neural progenitor cells raised the possibility that the virus contributes to the development of HAD not only by injuring and killing existing neurons but also by preventing potential repair mechanisms in the CNS (Figure 2).

\section{Mechanisms of Neuronal Injury and Death in HAD}

How HIV infection results in neuronal injury as well as neurocognitive and motor impairment continues to remain a controversial topic. While there is general agreement that HIV does not infect neurons, the primary cause of the neuronal damage remains in question. There is evidence to support multiple theories for neuronal injury by various viral proteins, including Tat, Nef, Vpr and the Env proteins gp120 and gp41. ${ }^{4}$ These findings have led to at least two different theories on how HIV results in neuronal injury in the brain. The theories can be described as the 'direct injury' hypothesis and the 'indirect' or 'bystander effect' hypothesis. These two theories are not mutually exclusive, and the available data support a role for both, although an indirect form of neurotoxicity seems to predominate. ${ }^{4,9,107}$

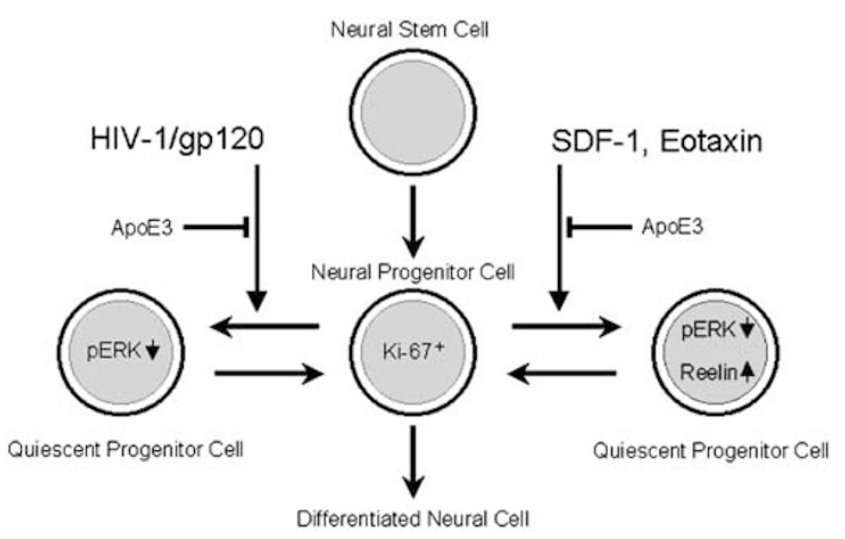

Figure 2 Interference of HIV-1/gp120 with the function of neural progenitor cells. Exposure to chemokines, SDF-1 and Eotaxin, or HIV-1/gp120 of mouse or human NPCs reduces proliferation and promotes quiescence. ApoE3 inhibits these effects on NPCs. NPCs express nestin and show decreased proliferation as judged by decreased BrdU incorporation. However, NPCs do not undergo apoptosis, as evidenced by lack of TUNEL staining and nuclear condensation under the same conditions ${ }^{105,106}$ (S Okamoto, S McKercher, M Kaul and SA Lipton, unpublished)

The theory that HIV proteins can directly injure neurons without requiring the intermediary function of non-neuronal cells (microglia and/or astrocytes) is supported by experiments showing that viral envelope proteins are toxic in serumfree primary neuronal cultures ${ }^{63}$ and in neuroblastoma cell lines. ${ }^{108}$ In these experimental paradigms, the impact of neurotoxic cytokines and EAAs secreted from non-neuronal cells is minimized because serum-free neuronal cultures contain few if any non-neuronal cells, and neuroblastoma lines do not contain cells of other phenotypes. The HIV coat protein gp120 interacts with several members of the chemokine receptor family (see above), and the direct form of HIVinduced neuronal injury may be mediated by chemokine receptor signaling. Indeed, experiments aimed at blocking chemokine receptor signaling can in some cases prevent HIV/ gp120-induced neuronal apoptosis. ${ }^{83,109}$ Additionally, nanomolar concentrations of gp120 have been reported to interact with the glycine binding site of the $\mathrm{N}$-methyl-D-aspartate-type glutamate receptor (NMDAR), ${ }^{110}$ suggesting another mechanism by which HIV/gp120 may have a direct effect on neuronal cell death. The HIV-protein Tat (HIV/Tat) can be taken up into PC12 cells by a receptor-mediated mechanism $^{64}$ and may also have a direct effect on neurons by potentiating the response to excitotoxic stimuli. ${ }^{111}$ Experiments using cultured hippocampal neurons revealed that the HIV-protein Vpr (HIV/Vpr) may be directly neurotoxic through formation of a cation-permeable channel. ${ }^{112}$ However, all of these in vitro findings must be interpreted in the context of the limitations of the experimental paradigm and concentration of HIV proteins employed. Most of the experimental results described above were obtained in the absence of nonneuronal cells and therefore a predominantly indirect effect would not be detected. In addition, the concentrations of HIV proteins employed were frequently well above the picomolar or lower range thought to be present in the brain or CSF from patients with HAD. 
Apoptotic neurons do not colocalize with infected microglia in HAD patients, ${ }^{113}$ supporting the hypothesis that HIV infection causes neurodegeneration through the release of soluble factors. Therefore, the propensity for cell-cell interactions mandates that disease pathogenesis in vitro be approached in a 'mixed' neuronal/glial primary culture system that recapitulates the type and proportion of cells normally found in the intact brain (Figure 1). Systems designed to study the effect of soluble factors released from microglia have included mixed cerebrocortical cultures from human fetal brain directly infected with $\mathrm{HIV},{ }^{113}$ severe combined immunodeficiency (SCID) mice inoculated with HIV-infected human monocytes, ${ }^{114}$ and mixed rodent cerebrocortical cultures exposed to picomolar concentrations of the envelope protein HIV/gp120. ${ }^{81,115,116}$

Using such in vitro models, we and others have found evidence for a predominantly indirect neurotoxic effect that occurs due to the response of non-neuronal cells to HIV infection or shed HIV proteins, as described previously. Much of the data supporting the theory of indirect neuronal injury stem from experiments designed to examine the toxicity of HIV envelope proteins or supernatants of infected macrophages. ${ }^{13,117,118}$ Picomolar concentrations of HIV/gp120 induce injury and apoptosis in primary rodent and human neurons. ${ }^{83,113,115,117}$ In our hands, the predominant mode of HIV/gp120 neurotoxicity to cerebrocortical neurons requires the presence of macrophages/microglia. ${ }^{15,81}$ Indeed, HIV-1infected or gp120-stimulated mononuclear phagocytes release neurotoxins that stimulate the NMDAR, as described earlier. NMDAR antagonists can ameliorate neuronal cell death in vitro due to HIV-infected macrophages or purified recombinant gp120, ${ }^{77,119,120}$ and in vivo in gp120 transgenic mice. ${ }^{121}$

Excessive stimulation of the NMDAR induces several detrimental intracellular signals that contribute to neuronal cell injury and subsequent death by apoptosis or necrosis, depending on the intensity of the initial insult (Figure 3). ${ }^{62}$ If the initial excitotoxic insult is fulminant, for example, in the ischemic core of a stroke, the cells die early from loss of ionic homeostasis, resulting in acute swelling and lysis (necrosis). If the insult is more mild, as seen in several neurodegenerative disorders including HAD, neurons enter a delayed death pathway known as apoptosis. ${ }^{62}$ Neuronal apoptosis after excitotoxic insult involves $\mathrm{Ca}^{2+}$ overload, activation of p38 MAP kinase and p53, release of cytochrome $c$ and other molecules such as apoptosis-inducing factor (AIF) from mitochondria, activation of caspases, free radical formation, lipid peroxidation and chromatin condensation. ${ }^{36,82,122-124}$ Activated caspase- 3 and p53 are prominently detected in neurons of brains from HAD patients, and, in vitro, p53 is indispensable in neurons (and microglia) for HIV-1/gp120 to cause neurotoxicity. ${ }^{82,125}$

The scaffolding protein PSD-95 (postsynaptic density-95) links the principal subunit of the NMDAR (NR1) with nNOS, a $\mathrm{Ca}^{2+}$-activated enzyme, and thus brings nNOS into close proximity to $\mathrm{Ca}^{2+}$ via the NMDAR-operated ion channel. ${ }^{126}$ Excessive intracellular $\mathrm{Ca}^{2+}$ overstimulates nNOS and protein kinase cascades with consequent generation of deleterious levels of free radicals, including reactive oxygen species (ROS) and NO. ${ }^{127} \mathrm{NO}$ can react with ROS to form cytotoxic peroxynitrite $\left(\mathrm{ONOO}^{-}\right){ }^{127}$ However, in alternative redox states, NO can activate p21 ras ${ }^{128}$ and inhibit caspases $^{129}$ via S-nitrosylation (transfer of the NO group to critical cysteine thiols), thereby attenuating apoptosis in cerebrocortical neurons. Oxidative processes and cell stress are also reflected by changes to the cellular lipid metabolism, and an increase in ceramide, sphingomyelin and hydroxynonenal has been implicated in the neurotoxic pathways associated with HAD. ${ }^{130}$

In addition to the intracellular effects of $\mathrm{NO}$ and oxidative stress, we have recently identified an extracellular proteolytic pathway to neuronal injury mediated by these effectors. In this pathway, S-nitrosylation (transfer of NO to a critical cysteine thiol group) and subsequent oxidation serve to activate MMP-9 and possibly other MMPs. ${ }^{131}$ Proteolytically active MMP-9 induces and promotes neuronal death presumably by disrupting the cellular mechanism(s) that allow essential attachment to the extracellular matrix and neighboring neurons.

Furthermore, we have found that neurons exposed to HIV/ gp120 and grown in mixed cerebrocortical cultures containing astrocytes and microglia demonstrate release of mitochondrial cytochrome $c$, caspase activation, chromatin condensation and apoptosis, which is blocked by inhibition of the p38 MAP kinase. ${ }^{81,125}$

In addition to chemokines and EAAs, HIV-infected or gp120-activated microglia also release inflammatory cytokines, including TNF- $\alpha$ and IL-1 $\beta .^{46,132}$ Among other actions, both of these cytokines stimulate release of L-cysteine from macrophages, and pharmacologic blockade of $\mathrm{IL}-1 \beta$ or antibody neutralization of $\mathrm{TNF}-\alpha$ prevents this release. ${ }^{60}$ Under physiological or pathophysiological conditions, Lcysteine can stimulate NMDARs and lead to neuronal apoptosis. ${ }^{60}$ TNF- $\alpha$ is capable of stimulating apoptosis in human neurons, ${ }^{133,134}$ but an indirect route of injury cannot be excluded. Expression of TNF- $\alpha$ and its receptor are elevated in brains from patients with HAD. ${ }^{46}$ Experiments aimed at addressing the question of interactions between neurotoxins associated with HAD have revealed that TNF- $\alpha$ and HIV/Tat synergize to promote neuronal death, and this effect is prevented by antioxidants. ${ }^{135}$ It remains possible that TNF- $\alpha$ can activate caspases within neurons via TNF- $\alpha$ receptor-1 (TNFR1), since TNFR1 is found on at least some neurons, and it can trigger caspase-8 activation. Indeed, we have found that antibody neutralization of TNF- $\alpha$ or inhibition of caspase- 8 prevents the neurotoxicity of HIV/gp120 in cultured cerebrocortical neurons, ${ }^{125}$ and caspase-8 activity can directly or indirectly activate caspase-3, leading to apoptosis. These findings suggest that inflammatory cytokines, including TNF- $\alpha$ and IL-1 $\beta$, may have important synergistic roles in HIVassociated neuropathology. 4,60,134,136

Transgenic (tg) mice expressing HIV-1/gp120 in their CNS manifest neuropathological features that are similar to the findings in brains of AIDS patients, including reactive astrocytosis, increased number and activation of microglia, reduction of synapto-dendritic complexity, loss of large pyramidal neurons, ${ }^{137}$ and induction of MMP-2. ${ }^{138}$ In addition, these gp120 tg mice display significant behavioral deficits, such as extended escape latency, and reduced swimming velocity and spatial retention. ${ }^{139}$ In gp120 tg mice, 


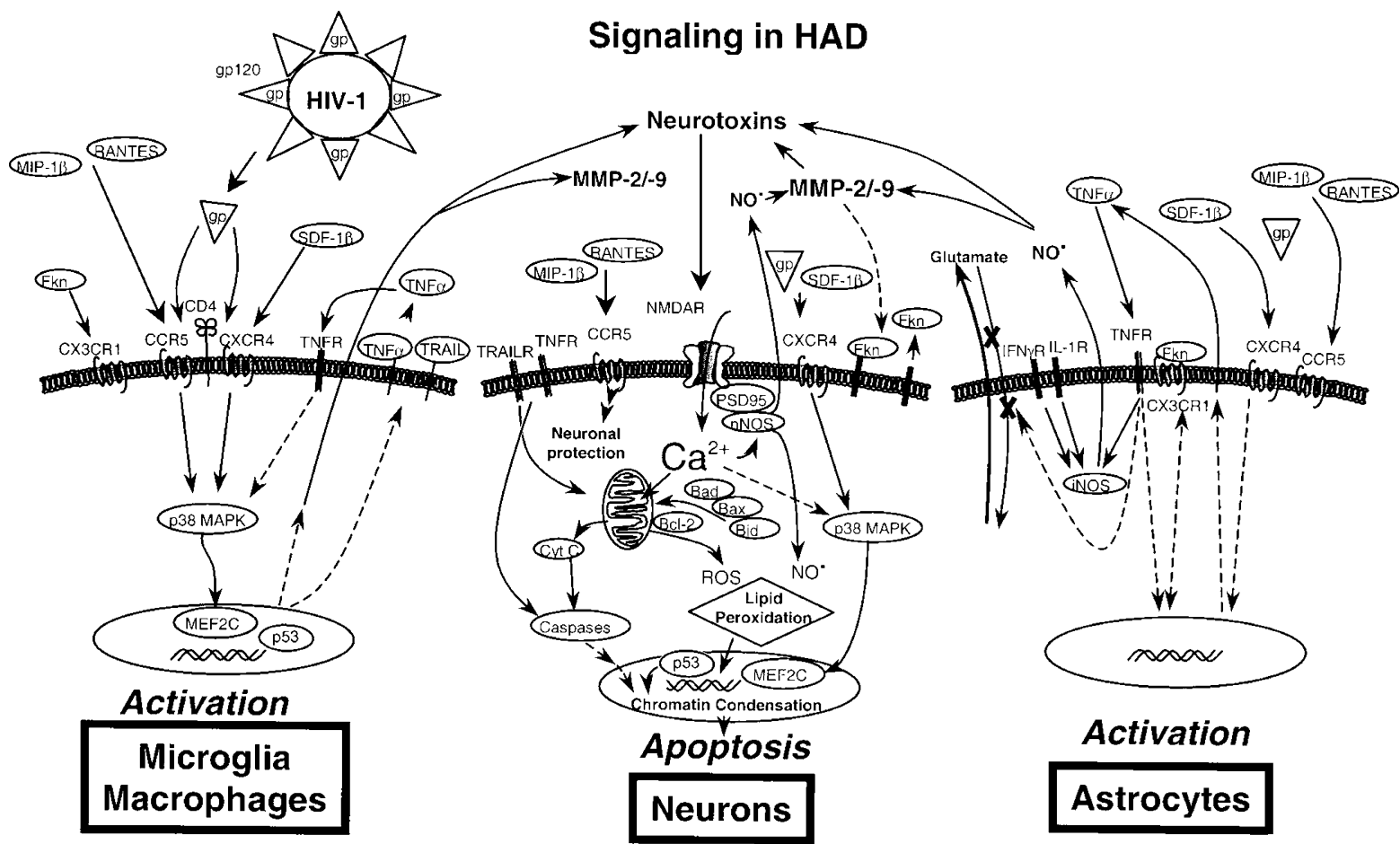

Figure 3 Cellular signaling in HAD - pathways engaged in neuronal injury and apoptosis. (Middle panel) Neuronal signaling in HAD: Overstimulation of the NMDAR is triggered by neurotoxins released from HIV-infected or immune-stimulated macrophages/microglia and by impaired clearance (or release) of glutamate that under normal conditions would have been taken up by astrocytes. Consequently, excessive $\mathrm{Ca}^{2+}$ influx into neurons triggers activation of p38 MAPK and p53, mitochondrial $\mathrm{Ca}^{2+}$ overload and cytochrome $c$ (cyt $c$ ) release, free radical generation (nitric oxide [NO ${ }^{\bullet}$ ] and reactive oxygen species [ROS]), caspase activation, and ultimately apoptosis. NMDARs are physically tethered to neuronal nitric oxide synthase (nNOS), facilitating its activation. NO passing out of the cell may activate MMPs and trigger an extracellular proteolytic pathway to neuronal injury. Inside the cell, the Bcl-2 family members Bad, Bax and Bid promote apoptosis mediated by glutamate, ROS and TNF- $\alpha /$ TRAIL, respectively. Bcl-2 prevents apoptosis, apparently by attenuating cytochrome $c$ release and ROS production. Activation of the p38 MAPK pathway by a $\mathrm{Ca}^{2+}$-mediated mechanism and by oxidative stress may lead to phosphorylation/activation of transcription factors involved in apoptosis, such as p53. Stimulation of the $\alpha$-chemokine receptor CXCR4 can also induce several pathways in neurons, including activation of p38 MAPK, which leads to apoptosis. In contrast, activation of the $\beta$ chemokine receptor CCR5 initiates an as yet uncharacterized neuroprotective pathway that interferes with toxicity triggered by HIV/gp120 or excessive stimulation of NMDARs. The chemokine fractalkine (Fkn) is released from neurons subsequent to excitotoxic injury, and may represent feedback signaling onto non-neuronal cells. (Left panel) Microglial/macrophage signaling in HAD: HIV/gp120 (gp) interacts with chemokine receptors CXCR4 or CCR5 in conjunction with CD4 to stimulate or infect (if the entire virus is present) microglia and macrophages. Natural ligands of CXCR4 (i.e., the $\alpha$-chemokine SDF-1) and CCR5 (i.e., the $\beta$-chemokines MIP-1 $\beta$ and RANTES) interfere with HIV/gp120 binding and signaling. However, only the $\beta$-chemokines can prevent the neurotoxic effect of activated microglia and macrophages. Neurons release the $\delta$-chemokine fractalkine (Fkn), which activates microglia. Hence, Fkn may mediate communication between neurons and glia. The HIV envelope protein gp120 triggers a signaling pathway that involves p38 MAPK, a pivotal factor in immune stimulation of macrophages that in turn activates the transcription factor MEF2C, and directly or indirectly also p53. HIV/gp120 induces the release of neurotoxic substances, including EAAs, arachidonic acid and related molecules such as $\mathrm{PAF}$, which engenders neuronal glutamate release. Furthermore, the HIV-1/gp120 also induces production of TRAIL and release of inflammatory cytokines, such as TNF- $\alpha$. Inflammatory cytokines can activate adjacent microglia/macrophages and astrocytes, and thus indirectly contribute to brain injury. (Right panel) Astrocyte signaling in HAD: Astrocytes express the HIV coreceptors CXCR4 and CCR5 in addition to other chemokine receptors, but lack CD4. Therefore, astrocytic reactivity may be influenced primarily by natural ligands of chemokine receptors. However, via these chemokine receptors, astrocytes may possibly also be stimulated by a CD4independent effect of HIV/gp120. Astrocytes are activated by inflammatory cytokines, including TNF- $\alpha, \mathrm{IL}-1 \beta$ and interferon- $\gamma$ (IFN- $\gamma$ ). Exposure to arachidonic acid released from macrophages/microglia and cytokine activation results in impaired glutamate uptake, increased glutamate release and induction of iNOS, leading to release of potentially neurotoxic NO. TNF- $\alpha$, released from macrophages/microglia, and SDF-1 stimulate astrocytes to release glutamate. TNF- $\alpha$ also promotes expression of the astrocytic fractalkine (Fkn) receptor CX3CR1. Stimulation of CX3CR1 on astrocytes induces release of a soluble factor that triggers microglial proliferation. The figure is modified from Kaul and Lipton ${ }^{199}$

neuronal damage is ameliorated by the NMDAR antagonist memantine. ${ }^{121}$ Memantine-treated gp120 tg and non-tg control mice retain a density of presynaptic terminals and dendrites that is similar to untreated non-tg/wild-type controls but significantly higher than in untreated gp120 tg animals. ${ }^{121}$ This finding confirms the hypothesis that the HIV-1 surface glycoprotein is sufficient to initiate excitotoxic neuronal injury and death. It also shows that an antagonist of NMDAR overstimulation can ameliorate HIV-associated neuronal damage in vivo. ${ }^{140}$

\section{Macrophages and Neuronal Injury in HAD}

Macrophages play a pivotal role, although somewhat paradoxical, in the pathobiology of HAD., ${ }^{441,142}$ Under steadystate conditions, mononuclear phagocytes, macrophages and microglia act as scavengers and sentinel cells, nonspecifically eliminating foreign material, and secreting trophic factors critical for maintenance of homeostasis within the CNS microenvironment. ${ }^{83,143-146}$ These protective functions, however, can evolve into destructive ones. A number of 
neurotrophins are secreted by macrophages. ${ }^{97}$ These factors include, but are not limited to, brain-derived neurotrophic factor (BDNF), ${ }^{147}$ insulin-like growth factor (IGF)-2, ${ }^{148} \beta$ nerve growth factor $(\beta \mathrm{NGF}),{ }^{149}$ transforming growth factor beta (TGF- $\beta){ }^{150}$ neurotrophin-3 (NT3) ${ }^{151}$ and glial-derived neurotrophic factor (GDNF). ${ }^{152}$ Clearly, a dysregulation of macrophage neurotrophic factors by viral infection and/or immune activation may occur during disease. This dysregulation may be as important as the production of neurotoxins for eliciting neuronal damage. Additionally, some neurotrophic factors are regulated by cytokines. For example, TNF- $\alpha$ (a candidate HIV-1-induced neurotoxin) produced by immune competent microglia can play a neurotrophic role by inducing biologically active TGF- $\beta .{ }^{150}$ TGF- $\beta$ is a protective cytokine for mammalian neurons, particularly in protection against glutamate neurotoxicity, hypoxia and gp120-mediated neural injury. $^{153}$ This cytokine also affects long-term synaptic facilitation. ${ }^{141}$

HIV establishes a latent and persistent infection within macrophages. ${ }^{8}$ The majority of HIV within the CNS appears to be localized within perivascular and blood-derived parenchymal brain macrophages and microglia. ${ }^{8}$ Astrocytes, oligodendrocytes and brain endothelial cells are rarely infected, if at all. ${ }^{154}$ As a result of viral infection and resultant immune activation, macrophages produce and release a variety of neurotoxins within the brain. ${ }^{4,155,156}$ These products comprise not only viral proteins, such as gp $120,{ }^{115} \mathrm{gp} 41^{157}$ and Tat, ${ }^{158}$ but also host cell-encoded products including platelet-activating factor (PAF), ${ }^{159}$ glutamate, ${ }^{49}$ arachidonic acid and its metabolites, ${ }^{160}$ proinflammatory cytokines, such as IL-1 $\beta$, TNF- $\alpha$, TNF-related apoptosis-inducing ligand (TRAIL), ${ }^{136,161}$ quinolinic acid, ${ }^{48,162} \mathrm{NTox}^{47}$ and $\mathrm{NO}^{157}$ among others. In this manner, macrophages, which were once pillars of the immune system, are now responsible for tissue damage, although it is still unclear how macrophages evolve from producing neurotrophins to producing neurotoxins. Perhaps, HIV-1 infection and immune activation induce a transition between neurotrophic and neurotoxic activities. In any case, it seems that activation of p53 in microglia plays a crucial role for neurotoxicity to occur upon exposure of the cells to HIV-1/gp120. ${ }^{82}$

\section{TRAIL}

Recent data suggest that specific subsets of peripherally activated monocytes may preferentially enter the brain and cause disease. ${ }^{9,163}$ The neurotoxicity of these subsets may be enhanced not only by changes in functional properties but also by the upregulation of specific cell-surface factors. One such factor is TRAIL: in a model using NOD-SCID mice and HIV-infected human peripheral blood mononuclear cells, it was shown recently that addition of lipopolysaccharide (LPS) causes the infected human cells to infiltrate the murine brain and to cause neuronal apoptosis. This effect was not only specific for macrophage-tropic HIV-1 but was also prevented by a neutralizing anti-TRAIL antibody. ${ }^{164}$ These findings strongly suggested a role for TRAIL in the induction of neuronal death by infected human macrophages. However, even though TRAIL has been reported to induce apoptosis in brain cells, ${ }^{165}$ it remains to be shown whether or not killing of neurons occurs as a consequence of a direct or indirect interaction.

TRAIL is a type II integral membrane protein. It is a member of the TNF superfamily and is closely related to FAS ligand. ${ }^{166}$ TRAIL interacts with at least five unique receptors found on a variety of cell types. TRAIL receptor 1 and 2 (TRAIL-R1 and TRAIL-R2) have death domains and induce cellular apoptosis following ligand binding. ${ }^{167}$ TRAIL-R3 and TRAIL$\mathrm{R} 4$, however, do not possess these domains and instead act as decoy receptors. ${ }^{168}$ The fifth soluble TRAIL receptor is osteoprotegerin. $^{169}$

\section{TRAIL and Apoptosis Signaling}

TRAIL receptor-mediated signaling events leading to apoptosis can be divided into two distinct pathways, involving either mitochondria (intrinsic) or death receptors (extrinsic) ${ }^{170}$ (for review, see Green ${ }^{171}$ ). The mitochondrial pathway is initiated through various stress signals that damage mitochondria. $\mathrm{Bcl}-$ 2 family proteins, including antiapoptotic members, that is, $\mathrm{Bcl}-2$ and $\mathrm{Bcl}-\mathrm{XL}$, and proapoptotic members, that is, Bax and Bak, play a critical role in this pathway. ${ }^{171}$ The $\mathrm{BH} 3-$ only $\mathrm{Bcl}-2$ family proteins, such as Bid, Bad, Bim and PUMA, serve as sentinels to these stress signals. They are activated through various means, including transcriptional activation, posttranslational modification, proteolytic cleavage, etc., during apoptosis. $^{172}$

In the death receptor (extrinsic) pathway, it has been suggested that during the activation of death receptors DR4 (TRAIL R1) and DR5 (TRAIL R2) by TRAIL, the receptor undergoes oligomerization upon activation, at which time the adapter protein Fas-associated death domain (FADD) is recruited. The receptor-FADD complex then recruits procaspase-8, which together form the death-inducing signaling complex (DISC) where procaspase- 8 is activated. ${ }^{173}$ Depending on the cell type, active caspase- 8 can directly lead to the activation of downstream effector caspases, including caspase-3, -6 and $-7 .^{174}$

While the death receptor (extrinsic) pathway and mitochondrial (intrinsic) pathway for apoptosis are capable of operating independently, accumulating evidence suggests that crosstalk between the two pathways exists in cells. ${ }^{171}$ Recently, Deng et al. ${ }^{170}$ demonstrated that mitochondrial events are required for TRAIL-mediated apoptosis using human colon cancer cells. They discovered that the reason for this requirement is the presence of negative regulation of the caspase cascade by XIAP, a widely expressed inhibitor of apoptosis protein (IAP) member. Binding of mitochondrially released Smac (also known as DIABLO) to XIAP antagonizes the caspase-XIAP interaction, thereby promoting apoptosis. ${ }^{175}$ It remains to be shown to what degree these pathways to cell death are operative in the brains of AIDS patients, but we observed in vitro that HIV-1/gp120 activated both the extrinsic and intrinsic pathways to neuronal apoptosis. $^{125}$ 


\section{Potential Strategies for Prevention or Therapy of HAD}

Presently, an effective pharmacotherapy for HAD is not available. Previous approaches to cope with HAD reflect the challenging complexity inherent in the treatment of patients with AIDS (reviewed by Melton et al. ${ }^{176}$ and Clifford $^{177}$ ). Previous and current therapeutic approaches include various anti-retroviral compounds, alone or in combination, such as Zidovudine, Didanosine, Zalcitabine, and Stavudine. Of these, however, only Zidovudine has been shown to cross the BBB to some extent. Zidovudine has a beneficial effect on $H A D$ but the effect is not long lasting. The other antiretroviral drugs may not penetrate the brain sufficiently to eradicate the virus in the CNS. Thus, an adjunctive treatment besides antiretroviral drugs is needed.

Based on the evolving pathogenesis of HAD described above, several potential therapeutic strategies to attenuate neuronal damage are worth exploring. Among others, agents warranting consideration include NMDAR blockers, cytokines, chemokines, chemokine and cytokine receptor antagonists, p38 MAPK inhibitors, caspase inhibitors and antioxidants (free radical scavengers or other inhibitors of excessive NO or ROS).

NMDAR antagonists have been shown to attenuate neuronal damage due to either HIV-infected macrophages or $\mathrm{HIV/gp120,} \mathrm{both} \mathrm{in} \mathrm{vitro} \mathrm{and} \mathrm{in} \mathrm{vivo.} \mathrm{The} \mathrm{open-channel}$ blocker, memantine, prevents excessive NMDAR activity while sparing physiological function. ${ }^{119,178}$ Also, unlike other NMDAR antagonists tested in clinical trials to date, memantine has proven both safe and effective in a number of phase III clinical trials for Alzheimer's disease and vascular dementia. The results of a large, multicenter $\mathrm{NIH}$-sponsored clinical trial using this agent in patients with HAD has suggested some benefit, and improved second-generation drugs are currently under development. Previous, small clinical trials of a voltage-activated calcium channel blocker, nimodipine, and a PAF inhibitor suggested some therapeutic benefit but were not conclusive. ${ }^{16,179,180}$ An additional clinical trial using the antioxidant drug selegiline is aimed at combating the effects of excitotoxicity by minimizing the impact of free radicals. ${ }^{181}$

Mood changes reaching the level of disorders are one of many problems associated with HIV-1 disease. Sodium valproate (VPA), which functions as a mood stabilizer, might be valuable as a part of the therapeutic armamentarium for HAD. Therapeutic concentrations of VPA $(0.6 \mathrm{mM})$ resulted in (1) significant increases in both nuclear and cytoplasmic $\beta$ catenin protein levels; (2) decreases in the level of protein $\alpha$ kinase $C$ and epsilon isozymes ${ }^{182}$ and (3) downregulation of myristoylated alanine-rich C-kinase substrate (MARCKS) ${ }^{183}$ through inositol-independent mechanisms. ${ }^{184}$ VPA-mediated neuroprotection involves diminished activity of GSK-3 $\beta$ via the inhibition of phosphorylation of $\beta$-catenin $\left(\mathrm{Ser}^{33,37}\right)$ and tau $\left(\mathrm{Ser}^{202}\right.$ and $\left.\mathrm{Thr}^{181}\right),{ }^{185}$ as well as the overall increase in total $\beta$-catenin protein levels (Figure 3 ). Hyperphosphorylation of $\beta$-Catenin and tau directly affects neuronal apoptosis and dysfunction. ${ }^{186} \beta$-catenin levels are markedly reduced in some neurodegenerative diseases, and decreased $\beta$-catenin signaling seems to increase neuronal vulnerability to apopto- sis. Thus, inhibition of GSK-3 $\beta$ may serve to offset the $\beta$ catenin destabilization, thereby reducing the vulnerability of affected neurons to apoptosis. In our studies using a model of HIV encephalitis (HIVE) in SCID mice, we found that hyperphosphorylation of $\beta$-catenin occurs in the basal ganglia concurrently with gliosis and neuronal degeneration. ${ }^{185}$ Similarly, specific phosphorylated isoforms of tau have been associated with neurodegenerative disorders, including $A D^{187}$ and, more recently, also HAD. ${ }^{185,188}$ In our model, highly phosphorylated tau at $\mathrm{Ser}^{202}$ and $\mathrm{Thr}^{181}$ is consistently associated with neuronal injury in SCID mice with the neuropathologic features of HIVE. Both tau and $\beta$-catenin may represent important physiologic targets of GSK-3 $\beta$ contributing to neuronal loss and neuronal damage in the context of HAD. ${ }^{185}$ The results support the hypothesis that downstream targets for pathologically activated GSK-3 $\beta$, including $\beta$-catenin and tau, might be a major event in the pathogenesis of HIVE or HAD. Furthermore, our data raise the possibility that VPA inhibits hyperphosphorylation of $\beta$-catenin and tau through the regulation of GSK-3 $\beta$, thus promoting neuronal survival. In connection with the same potentially protective mechanism, lithium has been suggested as a treatment for HAD because it similarly affects the phosphoinositol-3 kinase (PI3K)/Akt (protein kinase B)/GSK-3 $\beta$ pathway. ${ }^{189}$

Previously, we have shown that the cytokine erythropoietin (EPO) may not only be effective in treating anemia but also in protecting neurons, since it prevents NMDAR-mediated and HIV-1/gp120-induced neuronal death in mixed cerebrocortical cultures. ${ }^{190}$ Since EPO is already clinically approved for the treatment of anemia, human trials of EPO as a neuroprotectant from HIV-associated dementia may be expedited. ${ }^{191}$ Additionally, EPO plus IGF-1 act synergistically as neuroprotectants by activating the PI3K/Akt pathway; ${ }^{192}$ so the use of these two cytokines in conjunction has been advocated for clinical trials. ${ }^{191}$

Chemokine receptors allow HIV-1 to enter cells and as such are major potential therapeutic targets in the fight against AIDS. ${ }^{75,193}$ Antagonists of CXCR4 and CCR5 inhibit HIV-1 entry and are being assessed in clinical trials. ${ }^{75,193}$ However, the benefit of inhibitors of chemokine receptors for HIVassociated neurological complications, although likely, remains to be shown. ${ }^{9}$ Interestingly, as alluded to above, certain chemokines have been shown to protect neurons, even though the virus does not productively infect neurons. In particular, $\beta$-chemokines (acting on CCR5 receptors) and fractalkine prevent gp120-induced neuronal apoptosis in vitro, ${ }^{81,109,194}$ and, similarly, some $\beta$-chemokines can ameliorate NMDAR-mediated neurotoxicity. ${ }^{194}$ Additionally, HIV-infected patients with higher CSF concentrations of the $\beta$-chemokines MIP- $1 \alpha / \beta$ and RANTES performed better on neuropsychological measures than those with low or undetectable levels. ${ }^{195}$ These findings support the hypothesis that selected $\beta$-chemokines may represent a potential treatment modality for HAD.

Neuronal apoptosis appears to be one of the hallmarks of neurodegenerative diseases including HAD. ${ }^{53}$ Since caspases carry out the apoptotic program, caspase inhibitors may be helpful in preventing detrimental neuronal loss. ${ }^{196}$ As detailed above, caspases have been implicated in HIV-related 
neuronal damage. However, caspase inhibitors are not currently available in a form deliverable to the CNS or targeted to degenerating neurons. With further advances in the caspase field, such drugs may be developed. Care must be exerted to avoid inhibitors that promote oncogenic processes or interrupt physiologic circuits.

Finally, p38 MAPK inhibitors have been shown to reduce or abrogate neuronal apoptosis due to excitotoxicity, HIV/gp120 exposure or $\alpha$-chemokine (SDF-1) toxicity. ${ }^{81,197}$ The pharmaceutical industry is currently developing p38 inhibitors for a variety of inflammatory- and stress-related conditions, such as arthritis, and this may expedite trials for CNS indications such as HAD.

The most recent experimental evidence regarding HAD indicates that synergy between excitatory and inflammatory pathways to neuronal injury and death may, at least in part, be common to other CNS disorders including stroke, spinal cord injury and Alzheimer's disease. It seems likely therefore that the development of new therapeutic strategies for HAD will impact several other neurodegenerative diseases and possibly vice versa.

\section{Acknowledgements}

We sincerely apologize our colleagues whose works we could not cite owing to space and reference limitations. MK, JZ, HG and SAL are supported by the National Institutes of Health, R01 NS050621 (to MK), R01 NS 41858 (to JZ), R37 NS36126, 1T32, NS07488, 1P01 NS04398501, 5P01 MH64570-03 (to HEG) and P20 RR15635 (to HEG and JZ), P01 HD029587, R01 EY09024, R01 NS046994, R01 EY05477 and R01 NS41207 (to SAL). This work was also supported, in part, by Alan and Marcia Baer Foundation, the Fran V Blumbin Foundation Inc. (to HEG). SAL is a consultant to Allergan, Alcon, Forest Laboratories, NeuroMolecular Pharmaceuticals Inc. and Neurobiological Technologies Inc. in the field of neuroprotective agents.

\section{References}

1. Piot $P$, Bartos $M$, Ghys PD, Walker $N$ and Schwartlander $B$ (2001) The global impact of HIV/AIDS. Nature 410: 968-973

2. McArthur JC (1987) Neurologic manifestations of AIDS. Medicine (Baltimore) 66: 407-437

3. McArthur JC, Hoover DR, Bacellar H, Miller EN, Cohen BA, Becker JT, Graham NM, McArthur JH, Selnes OA and Jacobson LP (1993) Dementia in AIDS patients: incidence and risk factors. Multicenter AIDS Cohort Study. Neurology 43: 2245-2252

4. Kaul M, Garden GA and Lipton SA (2001) Pathways to neuronal injury and apoptosis in HIV-associated dementia. Nature 410: 988-994

5. Power C, Gill MJ and Johnson RT (2002) Progress in clinical neurosciences: the neuropathogenesis of HIV infection: host-virus interaction and the impact of therapy. Can. J. Neurol. Sci. 29: 19-32

6. Gendelman HE, Grant I, Lipton SA, Everall I and Swindells S (2005) The Neurology of AIDS 2nd edn (London: Oxford University Press)

7. Ellis RJ, Deutsch R, Heaton RK, Marcotte TD, McCutchan JA, Nelson JA, Abramson I, Thal LJ, Atkinson JH, Wallace MR and Grant I (1997) Neurocognitive impairment is an independent risk factor for death in HIV infection. San Diego HIV Neurobehavioral Research Center Group. Arch. Neurol. 54: 416-424

8. Koenig S, Gendelman HE, Orenstein JM, Dal Canto MC, Pezeshkpour GH, Yungbluth M, Janotta F, Aksamit A, Martin MA and Fauci AS (1986) Detection of AIDS virus in macrophages in brain tissue from AIDS patients with encephalopathy. Science 233: 1089-1093

9. Gartner S (2000) HIV infection and dementia. Science 287: 602-604

10. Persidsky $Y$, Zheng J, Miller D and Gendelman HE (2001) Mononuclear phagocytes mediate blood-brain barrier compromise and neuronal injury during HIV-1-associated dementia. J. Leukoc. Biol. 68: 413422

11. Budka H, Costanzi G, Cristina S, Lechi A, Parravicini C, Trabattoni R and Vago $L$ (1987) Brain pathology induced by infection with the human immunodeficiency virus (HIV). A histological, immunocytochemical, and electron microscopical study of 100 autopsy cases. Acta. Neuropathol. (Berl.) 75: $185-198$

12. Eilbott DJ, Peress N, Burger H, LaNeve D, Orenstein J, Gendelman HE, Seidman R and Weiser B (1989) Human immunodeficiency virus type 1 in spinal cords of acquired immunodeficiency syndrome patients with myelopathy: expression and replication in macrophages. Proc. Natl. Acad. Sci. USA 86: 3337-3341

13. Giulian D, Vaca K and Noonan CA (1990) Secretion of neurotoxins by mononuclear phagocytes infected with HIV-1. Science 250: 1593-1596

14. Genis P, Jett M, Bernton EW, Boyle T, Gelbard HA, Dzenko K, Keane RW, Resnick L, Mizrachi Y, Volsky DJ, Epstein L and Gendelman HE (1992) Cytokines and arachidonic metabolites produced during human immunodeficiency virus (HIV)-infected macrophage-astroglia interactions: implications for the neuropathogenesis of HIV disease. J. Exp. Med. 176: 1703-1718

15. Lipton SA and Gendelman HE (1995) Seminars in Medicine of the Beth Israel Hospital, Boston. Dementia associated with the acquired immunodeficiency syndrome. N. Engl. J. Med. 332: 934-940

16. Turchan J, Sacktor N, Wojna V, Conant K and Nath A (2003) Neuroprotective therapy for HIV dementia. Curr. HIV Res. 1: 373-383

17. Kaul M and Lipton SA (2004) Signaling pathways to neuronal damage and apoptosis in human immunodeficiency virus type 1-associated dementia: chemokine receptors, excitotoxicity, and beyond. J. Neurovirol. 10 (Suppl. 1): 97-101

18. Sacktor N, Lyles RH, Skolasky R, Kleeberger C, Selnes OA, Miller EN, Becker JT, Cohen B and McArthur JC (2001) HIV-associated neurologic disease incidence changes: Multicenter AIDS Cohort Study, 1990-1998. Neurology 56: $257-260$

19. Dore GJ, Hoy JF, Mallal SA, Li Y, Mijch AM, French MA, Cooper DA and Kaldor JM (1997) Trends in incidence of AIDS illnesses in Australia from 1983 to 1994: the Australian AIDS cohort. J. Acquir. Immune. Defic. Syndr. Hum. Retrovirol. 16: 39-43

20. Ferrando S, van Gorp W, McElhiney M, Goggin K, Sewell M and Rabkin J (1998) Highly active antiretroviral treatment in HIV infection: benefits for neuropsychological function. AIDS 12: F65-F70

21. Gendelman HE, Zheng J, Coulter CL, Ghorpade A, Che M, Thylin M, Rubocki R, Persidsky Y, Hahn F, Reinhard Jr. J and Swindells S (1998) Suppression of inflammatory neurotoxins by highly active antiretroviral therapy in human immunodeficiency virus-associated dementia. J. Infect. Dis. 178: 1000-1007

22. Dore GJ, Correll PK, Li Y, Kaldor JM, Cooper DA and Brew BJ (1999) Changes to AIDS dementia complex in the era of highly active antiretroviral therapy. AIDS 13: 1249-1253

23. Major EO, Rausch D, Marra C and Clifford D (2000) HIV-associated dementia. Science 288: 440-442

24. Enting RH, Hoetelmans RM, Lange JM, Burger DM, Beijnen JH and Portegies P (1998) Antiretroviral drugs and the central nervous system. AIDS 12: $1941-1955$

25. Cunningham PH, Smith DG, Satchell C, Cooper DA and Brew B (2000) Evidence for independent development of resistance to HIV-1 reverse transcriptase inhibitors in the cerebrospinal fluid. AIDS 14: 1949-1954

26. Lipton SA (1997) Treating AIDS dementia [letter; comment]. Science 276: $1629-1630$

27. Clifford DB (2000) Human immunodeficiency virus-associated dementia. Arch. Neurol. 57: 321-324

28. McArthur JC, McClernon DR, Cronin MF, Nance-Sproson TE, Saah AJ, St Clair M and Lanier ER (1997) Relationship between human immunodeficiency virus-associated dementia and viral load in cerebrospinal fluid and brain. Ann. Neurol. 42: 689-698 
29. Wiley CA, Soontornniyomkij V, Radhakrishnan L, Masliah E, Mellors J, Hermann SA, Dailey P and Achim CL (1998) Distribution of brain HIV load in AIDS. Brain Pathol. 8: 277-284

30. Nottet HS, Persidsky Y, Sasseville VG, Nukuna AN, Bock P, Zhai QH, Sharer LR, McComb RD, Swindells S, Soderland C and Gendelman HE (1996) Mechanisms for the transendothelial migration of HIV-1-infected monocytes into brain. J. Immunol. 156: 1284-1295

31. Persidsky $\mathrm{Y}$, Stins M, Way D, Witte MH, Weinand M, Kim KS, Bock P, Gendelman HE and Fiala M (1997) A model for monocyte migration through the blood-brain barrier during HIV-1 encephalitis. J. Immunol. 158: 3499-3510

32. Asensio VC and Campbell IL (1999) Chemokines in the CNS: plurifunctional mediators in diverse states. Trends Neurosci. 22: 504-512

33. Gonzalez E, Rovin BH, Sen L, Cooke G, Dhanda R, Mummidi S, Kulkarni H, Bamshad MJ, Telles V, Anderson SA, Walter EA, Stephan KT, Deucher M, Mangano A, Bologna R, Ahuja SS, Dolan MJ and Ahuja SK (2002) HIV-1 infection and AIDS dementia are influenced by a mutant MCP-1 allele linked to increased monocyte infiltration of tissues and MCP-1 levels. Proc. Natl. Acad. Sci. USA 99: 13795-13800

34. Prospero-Garcia O, Gold LH, Fox HS, Polis I, Koob GF, Bloom FE and Henriksen SJ (1996) Microglia-passaged simian immunodeficiency virus induces neurophysiological abnormalities in monkeys. Proc. Natl. Acad. Sci. USA 93: 14158-14163

35. Kalams SA and Walker BD (1995) Cytotoxic T lymphocytes and HIV-1 related neurologic disorders. Curr. Top Microbiol. Immunol. 202: 79-88

36. Mennicken F, Maki R, de Souza EB and Quirion R (1999) Chemokines and chemokine receptors in the CNS: a possible role in neuroinflammation and patterning. Trends Pharmacol. Sci. 20: 73-78

37. Zhao ML, Si Q and Lee SC (2004) IL-16 expression in lymphocytes and microglia in HIV-1 encephalitis. Neuropathol. Appl. Neurobiol. 30: 233-242

38. Sasseville VG, Newman W, Brodie SJ, Hesterberg P, Pauley D and Ringler DJ (1994) Monocyte adhesion to endothelium in simian immunodeficiency virus-induced AIDS encephalitis is mediated by vascular cell adhesion molecule-1/alpha 4 beta 1 integrin interactions. Am. J. Pathol. 144: 27-40

39. Fiala M, Looney DJ, Stins M, Way DD, Zhang L, Gan X, Chiappelli F, Schweitzer ES, Shapshak P, Weinand M, Graves MC, Witte M and Kim KS (1997) TNF-alpha opens a paracellular route for HIV-1 invasion across the blood-brain barrier. Mol. Med. 3: 553-564

40. Marshall DC, Wyss-Coray T and Abraham CR (1998) Induction of matrix metalloproteinase-2 in human immunodeficiency virus-1 glycoprotein 120 transgenic mouse brains. Neurosci. Lett. 254: 97-100

41. Bazan JF, Bacon KB, Hardiman G, Wang W, Soo K, Rossi D, Greaves DR Zlotnik A and Schall TJ (1997) A new class of membrane-bound chemokine with a CX3C motif. Nature 385: 640-644

42. Power C, McArthur JC, Nath A, Wehrly K, Mayne M, Nishio J, Langelier T, Johnson RT and Chesebro B (1998) Neuronal death induced by brain-derived human immunodeficiency virus type 1 envelope genes differs between demented and nondemented AIDS patients. J. Virol. 72: 9045-9053

43. Budka H (1991) Neuropathology of human immunodeficiency virus infection. Brain Pathol. 1: 163-175

44. Glass JD, Fedor H, Wesselingh SL and McArthur JC (1995) Immunocytochemical quantitation of human immunodeficiency virus in the brain: correlations with dementia. Ann. Neurol. 38: 755-762

45. Masliah E, Heaton RK, Marcotte TD, Ellis RJ, Wiley CA, Mallory M, Achim CL, McCutchan JA, Nelson JA, Atkinson JH and Grant I (1997) Dendritic injury is a pathological substrate for human immunodeficiency virus-related cognitive disorders. HNRC group. The HIV Neurobehavioral Research Center. Ann. Neurol. 42: 963-972

46. Wesselingh SL, Takahashi K, Glass JD, McArthur JC, Griffin JW and Griffin DE (1997) Cellular localization of tumor necrosis factor mRNA in neurological tissue from HIV-infected patients by combined reverse transcriptase/ polymerase chain reaction in situ hybridization and immunohistochemistry. J. Neuroimmunol. 74: 1-8

47. Giulian D, Yu J, Li X, Tom D, Li J, Wendt E, Lin SN, Schwarcz R and Noonan C (1996) Study of receptor-mediated neurotoxins released by HIV-1 infected mononuclear phagocytes found in human brain. J. Neurosci. 16 3139-3153

48. Heyes MP, Brew BJ, Martin A, Price RW, Salazar AM, Sidtis JJ, Yergey JA, Mouradian MM, Sadler AE, Keilp J, Rubinow D and Markey SP (1991)
Quinolinic acid in cerebrospinal fluid and serum in HIV-1 infection: relationship to clinical and neurological status. Ann. Neurol. 29: 202-209

49. Jiang ZG, Piggee C, Heyes MP, Murphy C, Quearry B, Bauer M, Zheng J, Gendelman HE and Markey SP (2001) Glutamate is a mediator of neurotoxicity in secretions of activated HIV-1-infected macrophages. J. Neuroimmunol. 117: 97-107

50. Everall IP, Heaton RK, Marcotte TD, Ellis RJ, McCutchan JA, Atkinson JH, Grant I, Mallory M and Masliah E (1999) Cortical synaptic density is reduced in mild to moderate human immunodeficiency virus neurocognitive disorder. HNRC group. HIV Neurobehavioral Research Center. Brain Pathol. 9: 209-217

51. Fox L, Alford M, Achim C, Mallory M and Masliah E (1997) Neurodegeneration of somatostatin-immunoreactive neurons in HIV encephalitis. J. Neuropathol. Exp. Neurol. 56: 360-368

52. Masliah E, Ge N, Achim CL, Hansen LA and Wiley CA (1992) Selective neuronal vulnerability in HIV encephalitis. J. Neuropathol. Exp. Neurol. 51: 585-593

53. Adle-Biassette H, Levy $\mathrm{Y}$, Colombel M, Poron F, Natchev S, Keohane $\mathrm{C}$ and Gray $F(1995)$ Neuronal apoptosis in HIV infection in adults. Neuropathol. Appl. Neurobiol. 21: 218-227

54. Gelbard HA, James HJ, Sharer LR, Perry SW, Saito Y, Kazee AM, Blumberg BM and Epstein LG (1995) Apoptotic neurons in brains from paediatric patients with HIV-1 encephalitis and progressive encephalopathy. Neuropathol. Appl. Neurobiol. 21: 208-217

55. Petito CK and Roberts B (1995) Evidence of apoptotic cell death in HIV encephalitis. Am. J. Pathol. 146: 1121-1130

56. Adle-Biassette H, Chretien F, Wingertsmann L, Hery C, Ereau T, Scaravilli F, Tardieu M and Gray F (1999) Neuronal apoptosis does not correlate with dementia in HIV infection but is related to microglial activation and axonal damage. Neuropathol. Appl. Neurobiol. 25: 123-133

57. Giulian D, Wendt E, Vaca K and Noonan CA (1993) The envelope glycoprotein of human immunodeficiency virus type 1 stimulates release of neurotoxins from monocytes. Proc. Natl. Acad. Sci. USA 90: 2769-2773

58. Lipton SA, Sucher NJ, Kaiser PK and Dreyer EB (1991) Synergistic effects of HIV coat protein and NMDA receptor-mediated neurotoxicity. Neuron 7: $111-118$

59. Brew BJ, Corbeil J, Pemberton L, Evans L, Saito K, Penny R, Cooper DA and Heyes MP (1995) Quinolinic acid production is related to macrophage tropic isolates of HIV-1. J. Neurovirol. 1: 369-374

60. Yeh MW, Kaul M, Zheng J, Nottet HS, Thylin M, Gendelman HE and Lipton SA (2000) Cytokine-stimulated, but not HIV-infected, human monocytederived macrophages produce neurotoxic levels of L-cysteine. J. Immunol. 164: 4265-4270

61. Zhao J, Lopez AL, Erichsen D, Herek S, Cotter RL, Curthoys NP and Zheng $\mathrm{J}$ (2004) Mitochondrial glutaminase enhances extracellular glutamate production in HIV-1-infected macrophages: linkage to HIV-1 associated dementia. J. Neurochem. 88: 169-180

62. Bonfoco E, Krainc D, Ankarcrona M, Nicotera P and Lipton SA (1995) Apoptosis and necrosis: two distinct events induced, respectively, by mild and intense insults with $\mathrm{N}$-methyl-D-aspartate or nitric oxide/superoxide in cortical cell cultures. Proc. Natl. Acad. Sci. USA 92: 7162-7166

63. Meucci O, Fatatis A, Simen AA, Bushell TJ, Gray PW and Miller RJ (1998) Chemokines regulate hippocampal neuronal signaling and gp120 neurotoxicity. Proc. Natl. Acad. Sci. USA 95: 14500-14505

64. Liu Y, Jones M, Hingtgen CM, Bu G, Laribee N, Tanzi RE, Moir RD, Nath A and $\mathrm{He} \mathrm{JJ}$ (2000) Uptake of HIV-1 Tat protein mediated by low-density lipoprotein receptor-related protein disrupts the neuronal metabolic balance of the receptor ligands. Nat. Med. 6: 1380-1387

65. Oberlin E, Amara A, Bachelerie F, Bessia C, Virelizier JL, ArenzanaSeisdedos F, Schwartz O, Heard JM, Clark-Lewis I, Legler DF, Loetscher M, Baggiolini M and Moser B (1996) The CXC chemokine SDF-1 is the ligand for LESTR/fusin and prevents infection by T-cell-line-adapted HIV-1. Nature 382 833-835

66. Tran PB and Miller RJ (2003) Chemokine receptors: signposts to brain development and disease. Nat. Rev. Neurosci. 4: 444-455

67. Ma Q, Jones D, Borghesani PR, Segal RA, Nagasawa T, Kishimoto $T$, Bronson RT and Springer TA (1998) Impaired B-lymphopoiesis, myelopoiesis, and derailed cerebellar neuron migration in CXCR4- and SDF-1-deficient mice. Proc. Natl. Acad. Sci. USA 95: 9448-9453 
68. Tachibana $\mathrm{K}$, Hirota $\mathrm{S}$, lizasa $\mathrm{H}$, Yoshida $\mathrm{H}$, Kawabata $\mathrm{K}$, Kataoka $\mathrm{Y}$, Kitamura $Y$, Matsushima K, Yoshida N, Nishikawa S, Kishimoto $T$ and Nagasawa T (1998) The chemokine receptor CXCR4 is essential for vascularization of the gastrointestinal tract. Nature 393: 591-594

69. Zou YR, Kottmann AH, Kuroda M, Taniuchi I and Littman DR (1998) Function of the chemokine receptor CXCR4 in haematopoiesis and in cerebellar development. Nature 393: 595-599

70. Locati M and Murphy PM (1999) Chemokines and chemokine receptors: biology and clinical relevance in inflammation and AIDS. Annu. Rev. Med. 50: 425-440

71. Lapidot T and Petit I (2002) Current understanding of stem cell mobilization: the roles of chemokines, proteolytic enzymes, adhesion molecules, cytokines, and stromal cells. Exp. Hematol. 30: 973-981

72. Alkhatib G, Combadiere C, Broder CC, Feng Y, Kennedy PE, Murphy PM and Berger EA (1996) CC CKR5: a RANTES, MIP-1alpha, MIP-1beta receptor as a fusion cofactor for macrophage-tropic HIV-1. Science 272: 1955-1958

73. Bleul CC, Farzan M, Choe H, Parolin C, Clark-Lewis I, Sodroski J and Springer TA (1996) The lymphocyte chemoattractant SDF-1 is a ligand for LESTR/fusin and blocks HIV-1 entry. Nature 382: 829-833

74. He J, Chen Y, Farzan M, Choe H, Ohagen A, Gartner S, Busciglio J, Yang X, Hofmann W, Newman W, Mackay CR, Sodroski J and Gabuzda D (1997) CCR3 and CCR5 are co-receptors for HIV-1 infection of microglia. Nature 385: 645-649

75. Michael NL and Moore JP (1999) HIV-1 entry inhibitors: evading the issue [news] [see comments]. Nat. Med. 5: 740-742

76. Ohagen A, Ghosh S, He J, Huang K, Chen Y, Yuan M, Osathanondh R, Gartner S, Shi B, Shaw G and Gabuzda D (1999) Apoptosis induced by infection of primary brain cultures with diverse human immunodeficiency virus type 1 isolates: evidence for a role of the envelope. J. Virol. 73: 897-906

77. Chen W, Sulcove J, Frank I, Jaffer S, Ozdener H and Kolson DL (2002) Development of a human neuronal cell model for human immunodeficiency virus (HIV)-infected macrophage-induced neurotoxicity: apoptosis induced by HIV type 1 primary isolates and evidence for involvement of the $\mathrm{Bcl}-2 / \mathrm{Bcl}-\mathrm{xL}$ sensitive intrinsic apoptosis pathway. J. Virol. 76: 9407-9419

78. Rottman JB, Ganley KP, Williams K, Wu L, Mackay CR and Ringler DJ (1997) Cellular localization of the chemokine receptor CCR5. Correlation to cellular targets of HIV-1 infection. Am. J. Pathol. 151: 1341-1351

79. Zhang L, He T, Talal A, Wang G, Frankel SS and Ho DD (1998) In vivo distribution of the human immunodeficiency virus/simian immunodeficiency virus coreceptors: CXCR4, CCR3, and CCR5. J. Virol. 72: 5035-5045

80. Hesselgesser J, Taub D, Baskar P, Greenberg M, Hoxie J, Kolson DL and Horuk R (1998) Neuronal apoptosis induced by HIV-1 gp120 and the chemokine SDF-1 alpha is mediated by the chemokine receptor CXCR4. Curr. Biol. 8: 595-598

81. Kaul M and Lipton SA (1999) Chemokines and activated macrophages in gp120-induced neuronal apoptosis. Proc. Natl. Acad. Sci. USA 96: 8212-8216

82. Garden GA, Guo W, Jayadev S, Tun C, Balcaitis S, Choi J, Montine TJ, Moller T and Morrison RS (2004) HIV associated neurodegeneration requires p53 in neurons and microglia. FASEB J. 18: 1141-1143

83. Zheng J, Thylin MR, Ghorpade A, Xiong H, Persidsky Y, Cotter R, Niemann D, Che M, Zeng YC, Gelbard HA, Shepard RB, Swartz JM and Gendelman HE (1999) Intracellular CXCR4 signaling, neuronal apoptosis and neuropathogenic mechanisms of HIV-1-associated dementia. J. Neuroimmunol. 98: $185-200$

84. Bezzi P, Domercq M, Brambilla L, Galli R, Schols D, De Clercq E, Vescovi A, Bagetta G, Kollias G, Meldolesi J and Volterra A (2001) CXCR4-activated astrocyte glutamate release via TNFalpha: amplification by microglia triggers neurotoxicity. Nat. Neurosci. 4: 702-710

85. Kaul M (2002) Chemokines and their receptors in HIV-associated dementia. J. Neurovirol. 8 (Suppl. 1): 41-42

86. McGrath KE, Koniski AD, Maltby KM, McGann JK and Palis J (1999) Embryonic expression and function of the chemokine SDF-1 and its receptor CXCR4. Dev. Biol. 213: 442-456

87. Gleichmann M, Gillen C, Czardybon M, Bosse F, Greiner-Petter R, Auer J and Muller HW (2000) Cloning and characterization of SDF-1gamma, a novel SDF-1 chemokine transcript with developmentally regulated expression in the nervous system. Eur. J. Neurosci. 12: 1857-1866
88. Stumm RK, Rummel J, Junker V, Culmsee C, Pfeiffer M, Krieglstein J, Hollt V and Schulz S (2002) A dual role for the SDF-1/CXCR4 chemokine receptor system in adult brain: isoform-selective regulation of SDF-1 expression modulates CXCR4-dependent neuronal plasticity and cerebral leukocyte recruitment after focal ischemia. J. Neurosci. 22: 5865-5878

89. Langford D, Sanders VJ, Mallory M, Kaul M and Masliah E (2002) Expression of stromal cell-derived factor 1alpha protein in HIV encephalitis. J. Neuroimmunol. 127: 115-126

90. Zhang K, McQuibban GA, Silva C, Butler GS, Johnston JB, Holden J, ClarkLewis I, Overall CM and Power C (2003) HIV-induced metalloproteinase processing of the chemokine stromal cell derived factor- 1 causes neurodegeneration. Nat. Neurosci. 6: 1064-1071

91. Johnston JB, Jiang Y, van Marle G, Mayne MB, Ni W, Holden J, McArthur JC and Power $C$ (2000) Lentivirus infection in the brain induces matrix metalloproteinase expression: role of envelope diversity. J. Virol. 74: 72117220

92. Sanders VJ, Pittman CA, White MG, Wang G, Wiley CA and Achim CL (1998) Chemokines and receptors in HIV encephalitis. AIDS 12: 1021-1026

93. McManus CM, Weidenheim K, Woodman SE, Nunez J, Hesselgesser J, Nath A and Berman JW (2000) Chemokine and chemokine-receptor expression in human glial elements: induction by the HIV protein, Tat, and chemokine autoregulation. Am. J. Pathol. 156: 1441-1453

94. Peng $\mathrm{H}$, Huang $\mathrm{Y}$, Rose J, Erichsen $\mathrm{D}$, Herek $\mathrm{S}$, Fujii $\mathrm{N}$, Tamamura $\mathrm{H}$ and Zheng $J$ (2004) Stromal cell-derived factor 1-mediated CXCR4 signaling in rat and human cortical neural progenitor cells. J. Neurosci. Res. 76: 35-50

95. Horner PJ and Gage FH (2000) Regenerating the damaged central nervous system. Nature 407: 963-970

96. van Praag H, Schinder AF, Christie BR, Toni N, Palmer TD and Gage FH (2002) Functional neurogenesis in the adult hippocampus. Nature 415: 1030-1034

97. Robinson AP, White TM and Mason DW (1986) Macrophage heterogeneity in the rat as delineated by two monoclonal antibodies MRC OX-41 and MRC OX-42, the latter recognizing complement receptor type 3. Immunology 57: $239-247$

98. Kokaia $Z$ and Lindvall $O$ (2003) Neurogenesis after ischaemic brain insults. Curr. Opin. Neurobiol. 13: 127-132

99. Santarelli L, Saxe M, Gross C, Surget A, Battaglia F, Dulawa S, Weisstaub N, Lee J, Duman R, Arancio O, Belzung C and Hen R (2003) Requirement of hippocampal neurogenesis for the behavioral effects of antidepressants. Science 301: 805-809

100. Zlotnik A, Morales J and Hedrick JA (1999) Recent advances in chemokines and chemokine receptors. Crit. Rev. Immunol. 19: 1-47

101. Jazin EE, Soderstrom S, Ebendal T and Larhammar D (1997) Embryonic expression of the mRNA for the rat homologue of the fusin/CXCR-4 HIV-1 coreceptor. J. Neuroimmunol. 79: 148-154

102. Lu M, Grove EA and Miller RJ (2002) Abnormal development of the hippocampal dentate gyrus in mice lacking the CXCR4 chemokine receptor. Proc. Natl. Acad. Sci. USA 99: 7090-7095

103. Stumm RK, Zhou C, Ara T, Lazarini F, Dubois-Dalcq M, Nagasawa T, Hollt V and Schulz S (2003) CXCR4 regulates interneuron migration in the developing neocortex. J. Neurosci. 23: 5123-5130

104. Ceradini DJ, Kulkarni AR, Callaghan MJ, Tepper OM, Bastidas N, Kleinman ME, Capla JM, Galiano RD, Levine JP and Gurtner GC (2004) Progenitor cell trafficking is regulated by hypoxic gradients through HIF-1 induction of SDF-1. Nat. Med. 10: 858-864

105. Krathwohl MD and Kaiser JL (2004) Chemokines promote quiescence and survival of human neural progenitor cells. Stem. Cells 22: 109-118

106. Krathwohl MD and Kaiser JL (2004) HIV-1 promotes quiescence in human neural progenitor cells. J. Infect. Dis. 190: 216-226

107. Zheng J, Thylin MR, Persidsky Y, Williams CE, Cotter RL, Zink W, Ryan L, Ghorpade A, Lewis K and Gendelman HE (2001) HIV-1 infected immune competent mononuclear phagocytes influence the pathways to neuronal demise. Neurotox. Res. 3: 461-484

108. Hesselgesser J, Halks-Miller M, DelVecchio V, Peiper SC, Hoxie J, Kolson DL, Taub D and Horuk R (1997) CD4-independent association between HIV-1 gp120 and CXCR4: functional chemokine receptors are expressed in human neurons. Curr. Biol. 7: 112-121 
109. Meucci O, Fatatis A, Simen AA and Miller RJ (2000) Expression of CX3CR1 chemokine receptors on neurons and their role in neuronal survival. Proc. Natl. Acad. Sci. USA 97: 8075-8080

110. Fontana $G$, Valenti $L$ and Raiteri $M(1997)$ gp120 can revert antagonism at the glycine site of NMDA receptors mediating GABA release from cultured hippocampal neurons. J. Neurosci. Res. 49: 732-738

111. Nath A, Haughey NJ, Jones M, Anderson C, Bell JE and Geiger JD (2000) Synergistic neurotoxicity by human immunodeficiency virus proteins Tat and gp120: protection by memantine. Ann. Neurol. 47: 186-194

112. Piller SC, Jans P, Gage PW and Jans DA (1998) Extracellular HIV-1 virus protein $R$ causes a large inward current and cell death in cultured hippocampal neurons: implications for AIDS pathology. Proc. Natl. Acad. Sci. USA 95: 4595-4600

113. Shi B, De Girolami U, He J, Wang S, Lorenzo A, Busciglio J and Gabuzda D (1996) Apoptosis induced by HIV-1 infection of the central nervous system. J. Clin. Invest. 98: 1979-1990

114. Xiong $H$, Zeng $Y C$, Lewis T, Zheng J, Persidsky $Y$ and Gendelman HE (2000) HIV-1 infected mononuclear phagocyte secretory products affect neuronal physiology leading to cellular demise: relevance for HIV-1-associated dementia. J. Neurovirol. 6: S14-S23

115. Brenneman DE, Westbrook GL, Fitzgerald SP, Ennist DL, Elkins KL, Ruff MR and Pert CB (1988) Neuronal cell killing by the envelope protein of HIV and its prevention by vasoactive intestinal peptide. Nature 335: 639-642

116. Kaiser PK, Offermann JT and Lipton SA (1990) Neuronal injury due to HIV-1 envelope protein is blocked by anti-gp120 antibodies but not by anti-CD4 antibodies. Neurology 40: 1757-1761

117. Dreyer EB, Kaiser PK, Offermann JT and Lipton SA (1990) HIV-1 coat protein neurotoxicity prevented by calcium channel antagonists. Science 248 364-367

118. Pulliam L, Herndier BG, Tang NM and McGrath MS (1991) Human immunodeficiency virus-infected macrophages produce soluble factors that cause histological and neurochemical alterations in cultured human brains. J. Clin. Invest. 87: 503-512

119. Lipton SA (1993) Prospects for clinically tolerated NMDA antagonists: openchannel blockers and alternative redox states of nitric oxide. Trends Neurosci. 16: 527-532

120. Gendelman HE, Genis P, Jett M, Zhai QH and Nottet HS (1994) An experimental model system for HIV-1-induced brain injury. Adv. Neuroimmunol. 4: 189-193

121. Toggas SM, Masliah E and Mucke L (1996) Prevention of HIV-1 gp120induced neuronal damage in the central nervous system of transgenic mice by the NMDA receptor antagonist memantine. Brain Res. 706: 303-307

122. Tenneti L, D'Emilia DM, Troy CM and Lipton SA (1998) Role of caspases in $\mathrm{N}$-methyl-D-aspartate-induced apoptosis in cerebrocortical neurons. J. Neurochem. 71: 946-959

123. Budd SL, Tenneti L, Lishnak T and Lipton SA (2000) Mitochondrial and extramitochondrial apoptotic signaling pathways in cerebrocortical neurons. Proc. Natl. Acad. Sci. USA 97: 6161-6166

124. Ghatan S, Larner S, Kinoshita Y, Hetman M, Patel L, Xia Z, Youle RJ and Morrison RS (2000) p38 MAP kinase mediates bax translocation in nitric oxide-induced apoptosis in neurons. J. Cell. Biol. 150: 335-347

125. Garden GA, Budd SL, Tsai E, Hanson L, Kaul M, D'Emilia DM, Friedlander RM, Yuan J, Masliah E and Lipton SA (2002) Caspase cascades in human immunodeficiency virus-associated neurodegeneration. J. Neurosci. 22: 4015-4024

126. Sattler R, Xiong Z, Lu WY, Hafner M, MacDonald JF and Tymianski M (1999) Specific coupling of NMDA receptor activation to nitric oxide neurotoxicity by PSD-95 protein. Science 284: 1845-1848

127. Nicotera P, Ankarcrona M, Bonfoco E, Orrenius S and Lipton SA (1997) Neuronal necrosis and apoptosis: two distinct events induced by exposure to glutamate or oxidative stress. Adv. Neurol. 72: 95-101

128. Gonzalez-Zulueta M, Feldman AB, Klesse LJ, Kalb RG, Dillman JF, Parada LF, Dawson TM and Dawson VL (2000) Requirement for nitric oxide activation of p21(ras)/extracellular regulated kinase in neuronal ischemic preconditioning. Proc. Natl. Acad. Sci. USA 97: 436-441

129. Tenneti L, D'Emilia DM and Lipton SA (1997) Suppression of neurona apoptosis by S-nitrosylation of caspases. Neurosci. Lett. 236: 139-142

130. Haughey NJ, Cutler RG, Tamara A, McArthur JC, Vargas DL, Pardo CA, Turchan J, Nath A and Mattson MP (2004) Perturbation of sphingolipid metabolism and ceramide production in HIV-dementia. Ann. Neurol. 55: 257-267

131. Gu Z, Kaul M, Yan B, Kridel SJ, Cui J, Strongin A, Smith JW, Liddington RC and Lipton SA (2002) S-nitrosylation of matrix metalloproteinases: signaling pathway to neuronal cell death. Science 297: 1186-1190

132. Persidsky Y, Buttini M, Limoges J, Bock P and Gendelman HE (1997) An analysis of HIV-1-associated inflammatory products in brain tissue of humans and SCID mice with HIV-1 encephalitis. J. Neurovirol. 3: 401-416

133. Pulliam L, Zhou M, Stubblebine M and Bitler CM (1998) Differential modulation of cell death proteins in human brain cells by tumor necrosis factor alpha and platelet activating factor. J. Neurosci. Res. 54: 530-538

134. Talley AK, Dewhurst S, Perry SW, Dollard SC, Gummuluru S, Fine SM, New D, Epstein LG, Gendelman HE and Gelbard HA (1995) Tumor necrosis facto alpha-induced apoptosis in human neuronal cells: protection by the antioxidant $\mathrm{N}$-acetylcysteine and the genes Bcl-2 and crma. Mol. Cell Biol. 15: 2359-2366

135. Shi B, Raina J, Lorenzo A, Busciglio J and Gabuzda D (1998) Neuronal apoptosis induced by HIV-1 Tat protein and TNF-alpha: potentiation of neurotoxicity mediated by oxidative stress and implications for HIV-1 dementia. J. Neurovirol. 4: 281-290

136. Ryan LA, Peng H, Erichsen DA, Huang Y, Persidsky $Y$, Zhou $Y$, Gendelman $\mathrm{HE}$ and Zheng J (2004) Links between TNF-related apoptosis-inducing ligand mediated human neuronal apoptosis and HIV-1-associated dementia J. Neuroimmunol. 148: 127-139

137. Toggas SM, Masliah E, Rockenstein EM, Rall GF, Abraham CR and Mucke L (1994) Central nervous system damage produced by expression of the HIV-1 coat protein gp120 in transgenic mice. Nature 367: 188-193

138. Marshall DC, Wyss-Coray T and Abraham CR (1998) Induction of matrix metalloproteinase-2 in human immunodeficiency virus-1 glycoprotein 120 transgenic mouse brains. Neurosci. Lett. 254: 97-100

139. D'hooge R, Franck F, Mucke L and De Deyn PP (1999) Age-related behavioural deficits in transgenic mice expressing the HIV-1 coat protein gp120. Eur. J. Neurosci. 11: 4398-4402

140. Anderson ER, Gendelman HE and Xiong H (2004) Memantine protects hippocampal neuronal function in murine human immunodeficiency virus type 1 encephalitis. J. Neurosci. 24: 7194-7198

141. Milligan CE, Cunningham TJ and Levitt $P$ (1991) Differential immunochemical markers reveal the normal distribution of brain macrophages and microglia in the developing rat brain. J. Comp. Neurol. 314: 125-135

142. Luo X, Carlson KA, Wojna V, Mayo R, Biskup TM, Stoner J, Anderson J, Gendelman HE and Melendez LM (2003) Macrophage proteomic fingerprinting predicts HIV-1-associated cognitive impairment. Neurology 60: 1931-1937

143. Elkabes S, DiCicco-Bloom EM and Black IB (1996) Brain microglia/ macrophages express neurotrophins that selectively regulate microglial proliferation and function. J. Neurosci. 16: 2508-2521

144. Lazarov-Spiegler O, Solomon AS, Zeev-Brann AB, Hirschberg DL, Lavie V and Schwartz M (1996) Transplantation of activated macrophages overcomes central nervous system regrowth failure. FASEB J. 10: 1296-1302

145. Rapalino O, Lazarov-Spiegler O, Agranov E, Velan GJ, Yoles E, Fraidakis M, Solomon A, Gepstein R, Katz A, Belkin M, Hadani M and Schwartz M (1998) Implantation of stimulated homologous macrophages results in partial recovery of paraplegic rats. Nat. Med. 4: 814-821

146. Gras G, Chretien F, Vallat-Decouvelaere AV, Le Pavec G, Porcheray F, Bossuet C, Leone C, Mialocq P, Dereuddre-Bosquet N, Clayette P, Le Grand R, Creminon C, Dormont D, Rimaniol AC and Gray F (2003) Regulated expression of sodium-dependent glutamate transporters and synthetase: a neuroprotective role for activated microglia and macrophages in HIV infection? Brain Pathol. 13: 211-222

147. Miwa T, Furukawa S, Nakajima K, Furukawa Y and Kohsaka S (1997) Lipopolysaccharide enhances synthesis of brain-derived neurotrophic factor in cultured rat microglia. J. Neurosci. Res. 50: 1023-1029

148. Nicholas RS, Stevens S, Wing MG and Compston DA (2002) Microgliaderived IGF-2 prevents TNFalpha induced death of mature oligodendrocytes in vitro. J. Neuroimmunol. 124: 36-44

149. Garaci E, Caroleo MC, Aloe L, Aquaro S, Piacentini M, Costa N, Amendola A, Micera A, Calio R, Perno CF and Levi-Montalcini R (1999) Nerve growth factor is an autocrine factor essential for the survival of macrophages infected with HIV. Proc. Natl. Acad. Sci. USA 96: 14013-14018 
150. Chao CC, Hu S, Sheng WS and Peterson PK (1995) Tumor necrosis factoralpha production by human fetal microglial cells: regulation by other cytokines. Dev. Neurosci. 17: 97-105

151. Kullander K, Kylberg A and Ebendal T (1997) Specificity of neurotrophin-3 determined by loss-of-function mutagenesis. J. Neurosci. Res. 50: 496-503

152. Batchelor PE, Liberatore GT, Wong JY, Porritt MJ, Frerichs F, Donnan GA and Howells DW (1999) Activated macrophages and microglia induce dopaminergic sprouting in the injured striatum and express brain-derived neurotrophic factor and glial cell line-derived neurotrophic factor. J. Neurosci. 19: $1708-1716$

153. Meucci $O$ and Miller RJ (1996) Gp120-induced neurotoxicity in hippocampal pyramidal neuron cultures: protective action of TGF-beta1. J. Neurosci. 16: 4080-4088

154. Tornatore C, Chandra R, Berger JR and Major EO (1994) HIV-1 infection of subcortical astrocytes in the pediatric central nervous system. Neurology 44 (Part 1): 481-487

155. Gendelman HE, Persidsky Y, Ghorpade A, Limoges J, Stins M, Fiala M and Morrisett R (1997) The neuropathogenesis of the AIDS dementia complex. AIDS 11 (Suppl. A): S35-S45

156. Nath A (1999) Pathobiology of human immunodeficiency virus dementia Semin. Neurol. 19: 113-127

157. Adamson DC, Wildemann B, Sasaki M, Glass JD, McArthur JC, Christov VI, Dawson TM and Dawson VL (1996) Immunologic NO synthase: elevation in severe AIDS dementia and induction by HIV-1 gp41. Science 274: 1917-1921

158. Nath A, Psooy K, Martin C, Knudsen B, Magnuson DS, Haughey N and Geiger JD (1996) Identification of a human immunodeficiency virus type 1 Tat epitope that is neuroexcitatory and neurotoxic. J. Virol. 70: 1475-1480

159. Gelbard HA, Nottet HS, Swindells $S$, Jett M, Dzenko KA, Genis $P$, White R, Wang L, Choi YB, Zhang D, Lipton SA, Tourtellotte WW, Epstein LG and Gendelman HE (1994) Platelet-activating factor: a candidate human immunodeficiency virus type 1-induced neurotoxin. J. Virol. 68: 4628-4635

160. Nottet HS, Jett M, Flanagan CR, Zhai QH, Persidsky Y, Rizzino A, Bernton EW, Genis P, Baldwin T, Schwartz J, LaBenz CJ and Gendelman HE (1995) A regulatory role for astrocytes in HIV-1 encephalitis. An overexpression of eicosanoids, platelet-activating factor, and tumor necrosis factor-alpha by activated HIV-1-infected monocytes is attenuated by primary human astrocytes. J. Immunol. 154: 3567-3581

161. Gelbard HA, Dzenko KA, DiLoreto D, del Cerro C, del Cerro M and Epstein LG (1993) Neurotoxic effects of tumor necrosis factor alpha in primary human neuronal cultures are mediated by activation of the glutamate AMPA receptor subtype: implications for AIDS neuropathogenesis. Dev. Neurosci. 15: 417-422

162. Kerr SJ, Armati PJ, Pemberton LA, Smythe G, Tattam B and Brew BJ (1997) Kynurenine pathway inhibition reduces neurotoxicity of HIV-1-infected macrophages. Neurology 49: 1671-1681

163. Fischer-Smith T, Croul S, Sverstiuk AE, Capini C, L'Heureux D, Regulier EG, Richardson MW, Amini S, Morgello S, Khalili K and Rappaport J (2001) CNS invasion by $\mathrm{CD} 14+/ \mathrm{CD} 16+$ peripheral blood-derived monocytes in HIV dementia: perivascular accumulation and reservoir of HIV infection. $\mathrm{J}$. Neurovirol. 7: 528-541

164. Miura $\mathrm{Y}$, Misawa N, Kawano $\mathrm{Y}$, Okada $\mathrm{H}$, Inagaki $\mathrm{Y}$, Yamamoto $\mathrm{N}$, Ito $\mathrm{M}$, Yagita H, Okumura K, Mizusawa $\mathrm{H}$ and Koyanagi $\mathrm{Y}$ (2003) Tumor necrosis factor-related apoptosis-inducing ligand induces neuronal death in a murine model of HIV central nervous system infection. Proc. Natl. Acad. Sci. USA 100: 2777-2782

165. Nitsch R, Bechmann I, Deisz RA, Haas D, Lehmann TN, Wendling U and Zipp $F(2000)$ Human brain-cell death induced by tumour-necrosis-factor-related apoptosis-inducing ligand (TRAIL). Lancet. 356: 827-828

166. Wiley SR, Schooley K, Smolak PJ, Din WS, Huang CP, Nicholl JK, Sutherland GR, Smith TD, Rauch C and Smith CA (1995) Identification and characterization of a new member of the TNF family that induces apoptosis. Immunity 3: 673-682

167. Pan G, O'Rourke K, Chinnaiyan AM, Gentz R, Ebner R, Ni J and Dixit VM (1997) The receptor for the cytotoxic ligand TRAIL. Science 276: 111-113

168. Degli-Esposti MA, Smolak PJ, Walczak H, Waugh J, Huang CP, DuBose RF, Goodwin RG and Smith CA (1997) Cloning and characterization of TRAIL-R3, a novel member of the emerging TRAIL receptor family. J. Exp. Med. 186: 1165-1170

169. Emery JG, McDonnell P, Burke MB, Deen KC, Lyn S, Silverman C, Dul E, Appelbaum ER, Eichman C, DiPrinzio R, Dodds RA, James IE, Rosenberg M,
Lee JC and Young PR (1998) Osteoprotegerin is a receptor for the cytotoxic ligand TRAIL. J. Biol. Chem. 273: 14363-14367

170. Deng $Y$, Lin $Y$ and Wu X (2002) TRAIL-induced apoptosis requires Baxdependent mitochondrial release of Smac/DIABLO. Genes Dev. 16: 33-45

171. Green DR (2003) The suicide in the thymus, a twisted trail. Nat. Immunol. 4: 207-208

172. Huang DC and Strasser A (2000) BH3-only proteins - essential initiators of apoptotic cell death. Cell 103: 839-842

173. Boatright KM, Renatus M, Scott FL, Sperandio S, Shin H, Pedersen IM, Ricci $\mathrm{JE}$, Edris WA, Sutherlin DP, Green DR and Salvesen GS (2003) A unified model for apical caspase activation. Mol. Cell. 11: 529-541

174. Ashkenazi A and Dixit VM (1998) Death receptors: signaling and modulation. Science 281: 1305-1308

175. Goyal L (2001) Cell death inhibition: keeping caspases in check. Cell 104: 805-808

176. Melton ST, Kirkwood CK and Ghaemi SN (1997) Pharmacotherapy of HIV dementia. Ann. Pharmacother. 31: 457-473

177. Clifford DB (1999) Central neurologic complications of HIV infection. Curr. Infect. Dis. Rep. 1: 187-191

178. Lipton SA (1992) Memantine prevents HIV coat protein-induced neuronal injury in vitro. Neurology 42: 1403-1405

179. Schifitto G, Sacktor N, Marder K, McDermott MP, McArthur JC, Kieburtz K, Small S and Epstein LG (1999) Randomized trial of the platelet-activating factor antagonist lexipafant in HIV-associated cognitive impairment* Neurological AIDS Research Consortium. Neurology 53: 391-396

180. Navia BA, Dafni U, Simpson D, Tucker T, Singer E, McArthur JC, Yiannoutsos C, Zaborski L and Lipton SA (1998) A phase I/II trial of nimodipine for HIVrelated neurologic complications. Neurology 51: 221-228

181. Sacktor N, Schifitto G, McDermott MP, Marder K, McArthur JC and Kieburtz K (2000) Transdermal selegiline in HIV-associated cognitive impairment: pilot, placebo-controlled study. Neurology 54: 233-235

182. Chen S and Hillman DE (1994) Immunohistochemical localization of protein kinase $C$ delta during postnatal development of the cerebellum. Brain Res. Dev. Brain Res. 80: 19-25

183. Manji HK, McNamara R, Chen G and Lenox RH (1999) Signalling pathways in the brain: cellular transduction of mood stabilisation in the treatment of manicdepressive illness. Aust. N Z J. Psychiatry 33 (Suppl.): S65-S83

184. Lenox RH, McNamara RK, Watterson JM and Watson DG (1996) Myristoylated alanine-rich C kinase substrate (MARCKS): a molecular target for the therapeutic action of mood stabilizers in the brain? J. Clin. Psychiatry 57 (Suppl 13): 23-31 discussion 32-33

185. Dou H, Birusingh K, Faraci J, Gorantla S, Poluektova LY, Maggirwar SB, Dewhurst S, Gelbard HA and Gendelman HE (2003) Neuroprotective activities of sodium valproate in a murine model of human immunodeficiency virus-1 encephalitis. J. Neurosci. 23: 9162-9170

186. Kim HS, Kim EM, Lee JP, Park CH, Kim S, Seo JH, Chang KA, Yu E, Jeong SJ, Chong YH and Suh YH (2003) C-terminal fragments of amyloid precursor protein exert neurotoxicity by inducing glycogen synthase kinase-3beta expression. FASEB J. 17: 1951-1953

187. Hong $M$ and Lee VM (1997) Insulin and insulin-like growth factor-1 regulate tau phosphorylation in cultured human neurons. J. Biol. Chem. 272: 19547-19553

188. Digicaylioglu M, Kaul M, Dowen R, Fletcher L and Lipton SA (2003) Combined neuroprotective effects of EPO IGF-I from Tau hyperphosphorylation HIV/ gp120-induced neuronal apoptosisAbstract Viewer/linerary Planner (Washington DC: Society for Neuroscience). Online Program No. 216.18

189. Everall IP, Bell C, Mallory M, Langford D, Adame A, Rockestein E and Masliah E (2002) Lithium ameliorates HIV-gp120-mediated neurotoxicity. Mol. Cell Neurosci. 21: 493-501

190. Digicaylioglu M, Kaul M, Fletcher L, Dowen R and Lipton SA (2004) Erythropoietin protects cerebrocortical neurons from HIV-1/gp120-induced damage. Neuroreport 15: 761-763

191. Lipton SA (2004) Erythropoietin for neurologic protection and diabetic neuropathy. N. Engl. J. Med. 350: 2516-2517

192. Digicaylioglu M, Garden G, Timberlake S, Fletcher L and Lipton SA (2004) Acute neuroprotective synergy of erythropoietin and insulin-like growth factor I. Proc. Natl. Acad. Sci. USA 101: 9855-9860

193. Wells TNC, Proudfoot AEI, Power CA, Lusti-Narasimhan M, Alouani S, Hoogewerf AJ and Peitsch MC (1996) The molecular basis of the chemokine/ 
chemokine receptor interaction - scope for design of chemokine antagonists. Methods 10: 126-134

194. Bruno V, Copani A, Besong G, Scoto G and Nicoletti F (2000) Neuroprotective activity of chemokines against $N$-methyl-D-aspartate or beta-amyloid-induced toxicity in culture. Eur. J. Pharmacol. 399: 117-121

195. Letendre SL, Lanier ER and McCutchan JA (1999) Cerebrospinal fluid beta chemokine concentrations in neurocognitively impaired individuals infected with human immunodeficiency virus type 1. J. Infect. Dis. 180: 310-319

196. Yuan J and Yankner BA (2000) Apoptosis in the nervous system. Nature 407: $802-809$
197. Kikuchi M, Tenneti L and Lipton SA (2000) Role of p38 mitogen-activated protein kinase in axotomy-induced apoptosis of rat retinal ganglion cells. J. Neurosci. 20: 5037-5044

198. Chapman GA, Moores K, Harrison D, Campbell CA, Stewart BR and Strijbos PJ (2000) Fractalkine cleavage from neuronal membranes represents an acute event in the inflammatory response to excitotoxic brain damage. J. Neurosci. (Online) 20: RC87

199. Kaul M and Lipton SA (2002) AIDS In: Ionotropic Glutamate Receptors as Therapeutic Targets, Lodge D, Danysz W, Parsons CG, eds (Mountain Home, TN: FP Graham Publishing Co) pp. 509-538 